Board of Governors of the Federal Reserve System

International Finance Discussion Papers

Number 1021

June 2011

\title{
Liquidity and Reserve Requirements in Brazil
}

\author{
Patrice Robitaille
}

NOTE: International Finance Discussion Papers are preliminary materials circulated to stimulate discussion and critical comment. References to International Finance Discussion Papers (other than an acknowledgment that the writer has had access to unpublished material) should be cleared with the author or authors. Recent IFDPs are available on the Web at www.federalreserve.gov/pubs/ifdp/. This paper can be downloaded without charge from Social Science Research Network electronic library at www.ssrn.com 


\title{
Liquidity and Reserve Requirements in Brazil
}

\author{
Patrice Robitaille*
}

\begin{abstract}
The international reform initiative that followed the global financial crisis of 2008-09 has resulted in the introduction of liquidity requirements for banks. Under one requirement, the Liquidity Coverage Ratio (LCR), banks will need to hold enough highly liquid assets to survive for a month in a stress scenario. Banks' required reserve balances can be used to fulfill this liquidity requirement and this may be seen as an attractive option for emerging market economies, where financial sectors are often underdeveloped. In this paper, I examine the Brazilian experience prior to and during the global crisis as a case study that can shed light into the challenges of using reserve requirements as a liquidity management tool. Brazilian reserve requirements did not ensure adequate liquidity, in part because the smallest banks were exempted from the requirements. Financial innovations were also used by banks to circumvent reserve requirements. In Brazil, the use of reserve requirements as a liquidity management tool is often justified by the argument that reserve requirements fulfilled a critical liquidity provision role in the fall of 2008. I argue that Brazilian reserve requirements did not actually serve well the liquidity provision goal.
\end{abstract}

Keywords: macro-prudential, reserve requirements, liquidity requirements, financial crisis of 2008-09, lender of last resort, Brazil.

JEL classification: E52, E53, E58, G18, G21, G28, N26, O16

* The author is staff economist in the International Finance Division and can be reached at patrice.robitaille@,frb.gov. An earlier version of this paper was presented at the International Finance Division's Global Financial Crisis Workshop at the Federal Reserve Board July 28-29, 2010, and was entitled "Brazilian Reserve Requirements as Macro-prudential and Crisis Management Tools." I would like to thank John Ammer, Katherine Bradley, Sally Davies, James Clouse, Jim Embersit, Mike Leahy, Tara Rice, and thank Sara Boyd of Economic Editing for helpful comments. I also thank Renato Baldini, Eduardo Lundberg and Tony Takeda of the Central Bank of Brazil for useful discussions and help with data. Jayme Bartling of Fitch IBCA patiently explained some features of structured finance in Brazil. Interviews with several people during a visit to Brazil in November 2009 were extremely helpful. Andrew Brooks, Quoctrung Bui, Karan Jain, Thomas Jones, and Justin Vitanza provided excellent research support. The views in this paper are solely the responsibility of the author and should not be interpreted as reflected the views of the Board of Governors of the Federal Reserve System or any other person associated with the Federal Reserve System. 
[T] he so-called developed world ...has reserve ratios of less than 10 percent, and we here have [a reserve ratio] of 53 percent on our demand deposits. What was in the past a defect has turned into advantage for us...

(Brazilian Finance Minister Guido Mantega quoted from interview in Folha de São Paulo, October 19, 2008b. $)^{1}$

\section{Introduction}

In response to the 2008-09 global financial crisis, the Basel Committee on Banking Supervision (BCBS) has proposed two new liquidity requirements for banks. The liquidity coverage ratio (LCR) will require banks to hold enough highly liquid assets to survive for a month in a stress scenario. Highly liquid assets are defined as those assets that can be readily converted into cash at little or no loss of value, namely, government bonds, certain private instruments, cash, and bank reserves. The second liquidity requirement, called the Net Stable Funding Ratio (NSFR), aims to limit maturity mismatches between a bank's assets and liabilities. ${ }^{2,3}$

For emerging market economies, implementing a liquidity requirement such as the LCR seems especially challenging because financial sectors are often underdeveloped and few assets could be considered liquid, particularly in times of stress. ${ }^{4}$ On the other hand, reserve requirements could be a more suitable liquidity management tool, as long

\footnotetext{
${ }^{1}$ All translations were done by the author.

2 The new liquidity requirements were unveiled in December 2009 (BCBS 2009) and amended requirements were released in December 2010 (BCBS 2010). The new liquidity requirements, along with new capital requirements, form the pillars of Basel III. The LCR is slated to go into effect in January 2015 and the NSFR is slated to go into effect in 2018.

${ }^{3}$ Brunnermeier, Gorton, and Krishnamurthy (BGK 2010) outline various approaches to the management of liquidity risk (see also CGFS 2010). The LCR conforms to BGK's "cash is king" notion of liquidity management. In contrast, Morris and Shin (2008) highlight the interaction between liquidity and leverage. In Brunnermaier and Yogo (2009), liquidity risk is managed by choosing the maturity structure of debt. ${ }^{4}$ In past periods of financial stress, investors have fled emerging market economy assets for safe havens.
} 
as the reserves meet the rule prescribed by the Basel Committee of being readily available in times of stress. In emerging market economies, reserve ratios can be high. Moreover, the central banks of Brazil, China, and Turkey, among others, have raised their reserve requirements over the past year to control credit growth.

In this paper, I examine the Brazilian experience with reserve requirements as a case study that can highlight the difficulties of using reserve requirements as a liquidity management tool. Brazil's case is of particular interest because, despite its high reserve ratios, reserve requirements have been seen as an increasingly important tool for managing liquidity risk. ${ }^{5}$ The liquidity management use for reserve requirements has been rationalized in part by the argument that reserve requirements fulfilled a critical liquidity provision role during the fall of 2008, when banks avoided the discount window, apparently for fear of being stigmatized. Consider the following comments by thenCentral Bank President Henrique Meirelles:

October 20, 2008:

Brazil has elevated required reserves, which ensure to banks a margin of guarantee of liquidity that is mandatory, deposited in the Central Bank, and which permits the monetary authority to irrigate liquidity to the system to the degree of its necessities" (Meirelles 2008, italics added for emphasis). ${ }^{6}$

August 2009:

If we had not had the compulsório [system of reserve requirements], we would not have been capable of reacting so quickly..." to funding pressures in local currency (Fernandes 2009).

However, reserve requirements also act as a tax that is equal to the foregone interest on the reserves. Historically, reserve requirements typically had fiscal motives (see

\footnotetext{
5 In February 2010, Brazilian central bank official Aldo Luiz Mendes, the Director of Monetary Policy, stated that "the compulsório (the reserve requirement system) is ... increasingly regarded as a liquidity cushion." Nakagawa and Graner (2010).

${ }^{6}$ Below, I describe exactly how the irrigation of liquidity was intended to work.
} 
Espinosa 1995), and reserve requirements have long been viewed as a source of "financial repression" in developing economies (McKinnon 1973, Shaw 1973, Fry 1995). Montero and Moreno (2011) document that reserve ratios in many emerging market economies, including Brazil, declined between 1990 and the mid-2000s. Very likely, policy makers concluded that high reserve requirements undermined efforts to promote financial sector development. However, the decline was not universal, and as noted above, monetary authorities in several countries have been raising reserve requirements. ${ }^{7}$

Among Brazilian economists, there has been considerable debate about to what extent the country's high reserve requirements contribute to the very high cost of credit. ${ }^{8}$ (Because substitutes for bank credit are not available for most borrowers whereas mutual funds can be a good substitute for bank deposits in Brazil, the incidence of the tax falls on borrowers.) In a relatively recently look at the issue, Brazilian central bank staffers, using accounting data, have found that the contribution of reserve requirements to the cost of credit is relatively small (Koyama, Annibal, Lundberg, Bader, and Takeda 2008). A counterargument, however, is that the measured contribution of reserve requirements to the cost of credit can be small because banks have succeeded at devising ways of avoiding the requirements.

The process of devising means to avoid high reserve requirements can in itself be costly, involving considerable time and effort. Furthermore, little attention has been given to the possibility that reserve requirements (as any regulation) could change bank

\footnotetext{
${ }^{7}$ Goodfriend and Hargraves (1983) document the evolution of prevailing views about the usefulness of reserve requirements in the United States. See also Feinman (1993).

${ }^{8}$ See Goldfajn, Hennings, and Mori (2003), Cardoso (2003), de Souza Rodrigues and Takeda (2004), and Carvalho and Azevedo (2008).
} 
behavior in undesirable ways. Krishnamurthy (2009) posits that a policy that requires banks to hold additional amounts of liquidity in non-crisis as well as in crisis states in certain situations may be "prohibitively costly since it distorts private sector actions in non-crisis states, and these states may be the more likely ones."

These considerations motivate this closer look at the Brazilian case. I focus on the period leading up to the global financial crisis and the fall of 2008, drawing on several sources, including the official record, press reports, and interviews with market participants and informed observers. I first describe the improvements in the macroeconomic and legal environments in the mid-2000s that made reserve requirements an increasingly binding constraint on banks' desire to lend. Banks found means of circumventing the requirements and small banks were exempted from the requirements. Some of the funding that ran off in the fall of 2008 was not in the base of the reserve requirements. I then argue that the reserve requirements system could not have met its liquidity provision goal as well as is contended in the fall of 2008 by explaining how the reserve requirements system became a de facto cross-subsidy scheme under which large banks were taxed to subsidize smaller banks. I posit that direct and indirect assistance from government-owned or government-supported entities played a more crucial role in alleviating funding pressures at that time.

Although it is difficult to make broad generalizations from one case study, the Brazilian experience strongly suggests that an assessment of the benefits of reserve requirements as a liquidity management tool needs to take into account the potential costs, including consideration of the effects of the requirements on bank behavior. 
Brazil's experience in the fall of 2008 also makes it clear that reserve requirements cannot effectively supplant the lender of last resort role for the central bank.

\section{The Macroeconomic Backdrop}

In the years that preceded the global financial crisis, the Brazilian economy experienced its longest period of rapid growth since the 1970s, with growth in real GDP per capita averaging $3 \frac{1}{2}$ percent between 2004 and 2007. Unlike the experience of the 1970s, growth was achieved against a backdrop of a stable macroeconomic environment and under a democratically-elected government. ${ }^{9}$

As seen in Figure 1, the CDS premium on Brazilian government debt, a measure of credit risk, plummeted as Brazilian authorities surmounted a financial crisis in 2002 and declined to a low of 70 basis points in 2007. The low credit risk premium for Brazil in the mid-2000s paralleled developments around the world, and so reflected in part the favorable global environment and improved investor tolerance for risk. Brazil also benefited from growing demand for commodities from Asia and an improvement in its terms of trade. In addition, low interest rates in advanced countries and improved investor sentiment about business prospects in Brazil and other emerging market economies drew in capital flows from abroad.

Brazil's relatively stable macroeconomic policy environment also was a key factor in the country's favorable macroeconomic performance. As of late 2002, this achievement was far from assured, however, because it was not clear that incoming president Luiz Ignácio Lula da Silva (known as Lula) would continue the reform process that had begun under the previous government of Henrique Cardoso (1995-2002). In the

\footnotetext{
${ }^{9}$ In 1990, a democratically-elected president by direct elections took power, marking the final step of a multi-year transition from military to civilian leadership. Brazil had been under military rule since 1963 .
} 
mid-1990s, hoping to put an end to the country's record of macroeconomic instability, the Cardoso government embarked on a fiscal and monetary policy reform agenda. These efforts were greatly complicated by a banking crisis that resulted in a wave of bank failures and prompted the central bank to provide financial assistance to a number of banks, including several of the country's largest. Authorities also responded by bolstering banking supervision and enacting other banking reforms. In late 1998 and early 1999, Brazil experienced another crisis that culminated in the abandonment of a five-year experiment with a fixed exchange rate policy. The Cardoso government responded by introducing an inflation targeting regime. With the inflation target as a nominal anchor, the central bank managed to maintain inflation a single-digit level (Figure 2), despite the sizeable depreciation of the currency in 1999.

With the political transition to the left-leaning Lula government approaching in late 2002, widespread concerns that the Cardoso administration's reform agenda would be abandoned were fueled by the prospective departure of then-Central Bank President Arminio Fraga (1999-2002), who had presided over the institution of inflation targeting. The Brazilian central bank is not legally independent, and it is widely agreed that central bank independence is a precondition for favorable economic performance. ${ }^{10}$ Fraga had been the longest-serving central bank president since the institution of democratic rule in 1990. ${ }^{11}$ By late 2002, Brazil was in the midst of a financial crisis that manifested itself in part in the form of a flight from Brazilian government debt, a sizeable depreciation of the real, and a surge in inflation.

\footnotetext{
${ }^{10}$ See Federal Reserve Chairman Ben Bernanke's speech of May 25, 2010 for an overview of the theoretical and empirical literature linking central bank independence and economic performance. See also Mishkin (2004).

${ }^{11}$ The eight central bank presidents that served between 1990 and 1999 had tenures in office that ranged from 4 to 27 months.
} 
The Lula government responded to these circumstances by taking several steps to demonstrate its commitment to fiscal and monetary discipline. Lula's designated choice for central bank president was Henrique Meirelles, a well-respected former bank executive who had won a congressional seat in the 2002 elections. The Lula government pledged to adhere to the inflation targeting regime and to submit a bill to congress to grant legal autonomy to central bank. These steps helped stabilize the currency, which had depreciated considerably over the second half of 2002.

Meirelles served as central bank president under Lula's two terms in office, through 2010. ${ }^{12}$ Under Meirelles, there were three tightening episodes. In early 2003, the central bank continued the policy tightening phase that had been initiated in late 2002 . This policy path, along with the previous measures that had been taken by the Lula government, helped bring inflation back down to single digit levels. ${ }^{13}$ As seen in Figure 2, the central bank's target policy rate, the Selic rate, reached a peak of 26.5 percent in early 2003 and remained there until inflationary pressures waned. In September 2004, another monetary policy tightening phase began that resulted in a 375 basis point increase in the Selic rate, to 19.75 percent, by May 2005. A loosening phase began in October 2005 and resulted in the reduction in the Selic rate to 11.25 percent by September 2007. The third tightening phase began in April 2008 and resulted in a 250 basis point increase, to 13.75 percent, by early September $2008 .^{14}$

\footnotetext{
${ }^{12}$ In October 2006, Lula was elected to a second four-year term.

${ }^{13}$ See Tombini and Alves (2006) on the challenges facing the central bank in early 2003.

${ }^{14}$ Bevilaqua, Mesquita, and Minella (2007) interpret the central bank's experience during the Lula administration through late 2006. Bevilaqua and Mesquita served on the central bank's governing board.
} 
This very brief overview of Brazil's monetary policy experience and a look at Figure 2 indicates that under Meirelles, the central bank was responsive to inflation. ${ }^{15}$ On the other hand, the Lula government did not deliver on its campaign promise to grant political autonomy to the central bank. A proposed central bank independence law had been crafted under the tutelage of Lula's first finance minister, Antonio Palocci (Colitt 2004). However, press reports in early 2004 indicate that there was considerable opposition to the plan from within Lula's political party. Lula's support also seemed lukewarm, as according to The Wall Street Journal, Lula remarked that the central bank independence was a "preoccupation of academic dissertations of someone in Brazil" (Moffett 2004).

In late July 2004, allegations emerged in the press that Meirelles and a central bank board member were being investigated for tax evasion. ${ }^{16}$ The central bank issued press releases, denying the allegations. The Economist (2004), observing that Finance Minister Palocci had again tried to amass support for the unpopular central bank independence proposal, remarked that "[s]ome analysts attribute the circulation of embarrassing stories about central bankers' taxes to foes of the institution's independence." There had also been considerable dissatisfaction about the conservative monetary policy stance. The Selic rate had been reduced from 26.5 percent to 16.5 percent between May and December 2003, with a rate drop at each monthly meeting, but the pace of further policy rate reductions slowed considerably over the first

\footnotetext{
${ }^{15}$ Inflation did surpass the upper bound of the inflation targeting range in 2002 and 2003, and as is prescribed under the inflation targeting regime, an open letter from Meirelles to the finance minister described the reasons for the overshooting, the measures that the central bank would take to ensure the convergence of inflation to the target, and the time span under which the measures were expected to have effect. An overshooting of the inflation target for 2001 triggered a similar letter from Fraga.

${ }^{16}$ The allegations appeared in weekly magazine IstoÉ.
} 
few months of 2004. ${ }^{17}$ At its May 2004 meeting, the central bank held the Selic rate at 16 percent and maintained the benchmark rate at that level at its June and July meetings.

Against this backdrop and the emergence in early August of new allegations of financial misconduct by Meirelles, in mid-August, Lula enacted a measure that granted the central bank president the same legal protections as a minister. A minister is better protected from outside political pressures because any lawsuit involving a minister needs to be strong enough to be considered by the Supreme Court. ${ }^{18}$ The measure was approved by both houses of congress and become law in December 2004. The law was subsequently challenged before the Supreme Court, which ruled in favor of the Lula government in May 2005.

In mid-2005, the effort that had been led by Finance Minister Palocci to strengthen central bank independence was derailed by a major political scandal (the socalled mensalão). The scandal dominated national attention for several months, with the more pessimistic observers expressing the possibility that Lula would be impeached (see UBS 2005). Although Lula survived this challenge, the scandal resulted, among other things, in the departure of Palocci in March 2006. The new finance minister was Guido Mantega, previously the minister of planning. By mid-2006, the central bank independence law was no longer a priority of the Lula government. In August 2006, Mantega stated that "[w]e always take gradual measures and we will continue along that path" (Colitt and Bianconi 2006. See also Dow Jones 2005).

\footnotetext{
${ }^{17}$ Rate drops between the July and December 2003 meetings were large, ranging from 100 basis points to 250 basis points.

${ }^{18}$ The legal step that Lula took is called a provisional measure (medida provisória), which takes effect immediately but must have the subsequent approval of both houses of congress to avoid being overturned.
} 
The Lula government registered major accomplishments in the area of social policy. In the macroeconomic policy arena, a principal accomplishment was the improvement in debt management, which reduced the public sector's exposure to currency risk. As part of this effort, central bank built up a large stock of international reserves as a hedge against the risk of future crisis episodes that could be accompanied by large exchange rate depreciation. In other areas of fiscal management, the record is less clear. One view is that fiscal policy continued to be prudently managed so that fiscal dominance, that is, pressure on the central bank to monetize future fiscal deficits, was no longer a concern. That said, a number of critics argued that the fiscal stance was in fact pro-cyclical in much of Latin America during the economic boom years of the mid-2000s (see, for example, Catão, Cavallo, Izquierdo, Powell, and Talvi 2008). In addition, reports of tensions between Mantega and central bank officials over monetary policy repeatedly surfaced in the press (see, for example, Reuters 2007, Romero 2010).

To what extent these developments fueled skepticism about the central bank's ability to anchor inflation expectations is not clear. Shown in Figure 2 is the mean forecast of long-term inflation (five- to ten-year ahead) from the bi-annual Consensus Forecasts survey. This measure of long-term inflation expectations is compared with the inflation target, also shown. The targets for 2003 and 2004 shown in Figure 2 were subsequently revised up, but the original targets are shown because these target announcements were more likely closer to the government's implicit long-term inflation goal. ${ }^{19}$ Arguably, long-term inflation expectations have been anchored since 2005, as the mean long-term inflation forecast has been close to or below the inflation target. On the

${ }^{19}$ Because neither the Cardoso nor the Lula government announced long-term inflation targets, one cannot rule out the possibility that the two governments had different long-term inflation goals. 
other hand, the fact that financial indexation remains pervasive in Brazil is a sign that worries about the risk of future inflation continue to linger. Yields on the lion's share of bank certificates of deposit and other financial instruments are linked to either an overnight interest rate or a price index, and a very small portion of public debt is longterm fixed-rate debt (with maturities of over 5 years). ${ }^{20}$

\section{2004 to 2008: The Credit Boom}

According to Goldfajn, Hennings, and Mori (2003), over most of the late 1990s and the early 2000s, Brazilian banks held a large portion of their assets in the form of government bonds and interbank loans "for precautionary motives." Government debt was largely linked to the Selic rate or (until the mid-2000s) to the dollar, which helped insulate investors from macroeconomic risks. In addition, the demand for credit was limited as a result of its very high cost.

In 2003 , credit to the private sector stood at only 25 percent of GDP, well below that of neighboring Chile and emerging Asia. Moreover, nearly 40 percent of total credit to the private sector was government-directed. Much of this credit came from the massive government development bank, the BNDES (Banco Nacional de Desenvolvimento Económico e Social), which serves the corporate sector and has been (and continues to be) virtually the only source of long-term credit that is available domestically. The BNDES' loan rates, which have been well below market levels, are linked to an interest rate called the TJLP (taxa de juros de longo prazo, not shown) that is

\footnotetext{
${ }^{20}$ Between 2005 and 2007, the Brazilian government issued three real-denominated Global bonds that matured in 2016, 2022, and 2022. Yields on these Global bonds remained in double digit territory until mid-2007. The yield on the longest-maturity issue, which matures in 2028, declined from 10.68 percent when it was issued February 2007 to under 9 percent the following May. However, these bonds were a very small portion of total government debt. As of December 2007, the amount outstanding totaled $\mathrm{R} \$ 11.3$ billion, which amounted to less than 2 percent of the central government total outstanding debt. There were no domestic issues of nominal government bonds with maturities of at least 10 years.
} 
set on a quarterly basis by the three-member National Monetary Council (CMN). ${ }^{21}$ The CMN is composed of the finance and planning ministers and the central bank president and is the highest regulatory authority for depositories and other financial institutions in Brazil.

By 2004, Brazil was in the early stages of a credit boom that was fueled by growth in non-earmarked (i.e., not government-directed) credit. In 2007, Brazilian credit to the private sector reached 35 percent of GDP -25 percent excluding governmentdirected credit. Figure 3 puts the credit boom into a longer term perspective by plotting credit to the private sector in constant December 2007 reais since 1995, when the central bank's credit series begins. The earlier credit aggregates are of more dubious quality in part because credit from government-owned banks, which accounted for well over half of total lending to the private sector, was often not provided with the expectation of being fully repaid (see Baer and Nazmi 2000, Salviano (2004). Macroeconomic instability in the 1980s and 1990s also discouraged lending, and depositor losses during the antiinflation plans that were experimented with in the late 1980s and early 1990s undermined confidence in banks. The high priority that was given to fiscal and monetary prudence in the mid-1990s plus the banking crisis prompted banking reforms that included the privatization of most state government-owned banks. Against this historical backdrop, the rapid credit growth that Brazil experienced in the mid-2000s took place amid a dramatically altered banking landscape.

\footnotetext{
${ }^{21}$ Hausmann (2008) argues that it would be impossible for the BNDES to monitor its borrowers well enough to ensure that the loans are used for the purposes that they were made, as opposed to being invested in government bonds or other safer instruments that yield the Selic Rate. Another way of looking at BNDES credit is to think of the loan market in Brazil as an example of price discrimination. There are the posted loan rates and then there are the selected borrowers who have access to relatively cheap credit. I thank Marvin Goodfriend for making this point.
} 
The credit boom was initially led by rapid growth in consumer credit, as can be seen in Figure 4. Consumer credit expanded rapidly following developments in the early 2000s that made it more attractive for banks to offer payroll loans (crédito consignado), which was viewed as less risky than other forms of consumer credit. ${ }^{22}$ In addition, several changes in banking regulation in the late 1990s and early 2000s made it possible for banks to expand their services geographically but at the same time avoid high labor costs and other costs of a branch network..$^{23,24}$ In 2007 and 2008, loans to firms led credit growth.

Loan-deposit spreads of Brazilian banks have been extraordinarily high by international standards. In Figure 5 (top panel) plots the average loan-deposit s--pread for outstanding loans to consumers and firms. The spread declined sharply in the early years of the inflation targeting regime. The average spread on consumer loans also declined following the 2002-03 crisis, which owed chiefly to the growing popularity of payroll and vehicle loans. Their relatively low loan rates (Figure 5 bottom panel) made these loans relatively attractive, prompting a substitution from other forms of credit. The

\footnotetext{
${ }^{22}$ Payroll loans have been considered less risky than other types of consumer credit because a bank has the legal authority to deduct automatically loan payments from a borrower's payroll check. Takeda and Bader (2005) and Coelho, Funchal, and De Mello (2010) describe the emergence and growth of payroll lending in the mid-2000s.

${ }^{23}$ Banks expanded their services geographically with the use of correspondent relationships. Kumar, Nair, Parsons, and Urdapilleta (2006) define correspondents as "bank partnerships with non-banks, typically retail commercial outlets, ranging from lottery kiosks, pharmacies, post offices, construction goods stores, and so forth, to provide distribution outlets for financial services." Their study is based on data through 2004. Correspondents at that time were primarily engaged in the provision of payments services, but in the mid-2000s, banks began to use correspondents and agents (popularly called pastinhas) to originate consumer loans.

${ }^{24}$ Because Brazilian bank employees are unionized, labor costs in the banking sector have been well above labor costs under correspondent relationships. Attesting to the fact that the cost differential is substantial, in early 2011, an official of the labor union of bank workers stated that if correspondents were recognized as bank employees, the banking sector would have an additional 500 thousand workers, practically doubling the existing workforce (Cotias 2011).
} 
cost of credit between 2005 and 2007 likely also declined by more than what is apparent in the figure, in part because loan maturities also lengthened over this period. ${ }^{25}$

\section{The Brazilian Financial System and Reserve Requirements}

Brazilian banks are authorized to operate various types of financial activities as “multiple banks," offering commercial banking, investment banking, development banking, mortgage finance, leasing, and other financial activities. Multiple banks are usually members of a banking conglomerate that can include commercial banks as well as other financial institutions. In addition, bank and non-bank financial institutions may be members of a conglomerate that includes industrial and commercial firms. ${ }^{26}$

In this paper, unless stated otherwise, a bank is either a banking conglomerate (which consists of a commercial bank and other financial institutions) or an independent commercial bank. (The BNDES has been one of the five biggest providers of credit to the private sector but it is not a depository institution.) The lead institution in the banking conglomerate is required to provide a consolidated financial statement to the central bank. Banking conglomerates do not include certain financial institutions, including insurance companies, and do not include mutual funds. Most of Brazil's mutual funds are managed by banks.

As of December 2007, Brazil had 101 banks. Twelve banks were owned by the federal and state governments and accounted for about 30 percent of total assets, while 55 privately-owned domestic banks and 34 foreign banks accounted for about 45 and

\footnotetext{
${ }^{25}$ According to central bank data, between December 2004 and December 2007, the average maturity of loans to consumers rose from 189 days to 275 days and for loans to firms rose from 296 to 439 days.

${ }^{26}$ Perhaps the most well-known conglomerate is the Votorantim group, which is reputed to be the largest conglomerate in Brazil. Its bank, Banco Votorantim, ran into trouble in the fall of 2008, as is discussed below. There appear to be no data that would shed light into the extent to which banks are members of conglomerates that include industrial and commercial firms.
} 
25 percent of total assets, respectively. Table 1 lists the country's ten largest banks by total assets in December 2007. The ten largest banks, which accounted for about 80 percent of system assets, included two federally-owned banks, Banco do Brasil and Caixa Economica Federal (CEF). ${ }^{27}$ Five banks were domestically-owned (Bradesco, Itaú, Unibanco, Votorantim, and Safra), and three were subsidiaries of foreign banks (ABN Amro, HSBC, and Banco Santander). Several of these banks would subsequently play or be asked to play important roles at the height of the global financial crisis in the fall of 2008. As can be seen by the last column of Table 1,9 of the 10 largest banks had extensive branch networks. Votorantim is the exception. However, as was noted above, many banks took advantage of the opportunity to expand their services geographically without adding branches.

Table 2 displays Brazilian statutory reserve requirements as of mid-January 2008. Brazil's complex system of reserve requirements can be categorized as comprising two types of requirements: those under which banks earn either no interest on their balances or earn an interest rate that is well below the Selic rate and those that earn the Selic rate. Demand and savings deposits are subject to the first type of reserve requirement. As can be seen, the statutory reserve ratios were very high, 45 percent for demand deposits and 20 percent for savings deposits. ${ }^{28}$ The reserve requirement for demand deposits includes a R\$44 million deductible, which means that if banks' required reserves fall below $\mathrm{R} \$ 98$ million, banks are exempted from the requirement.

\footnotetext{
${ }^{27}$ The CEF is 100 percent government-owned. The Brazilian government holds 100 percent of Banco do Brasil's shares with voting rights.

${ }^{28}$ In addition, demand and savings deposits were subject to directed lending requirements. Banks have been required to lend 27 percent of their demand deposits and 65 percent of their savings deposits to the agriculture and housing sectors, respectively. In the past, because loans to these sectors were very risky, the lending requirements were an implicit tax. However, loans to the housing sector have grown rapidly over the past year, apparently fueled by reforms that have reduced loan risk.
} 
As of January 2008, the second category of reserve requirements, under which banks earned the Selic rate on their balances, consisted of a cash requirement and a government bond holding requirement. The cash requirement is often referred to as the "extraordinary" reserve requirement (exigibilidade adicional) and was satisfied by holding a reserve account at the central bank. The reserve ratio was 8 percent for demand and time deposits and 10 percent for savings deposits. In the quote from Finance Minister Guido Mantega in the introduction of this paper, the 53 percent reserve ratio for demand deposits is the sum of the 45 percent reserve ratio where zero interest is earned on bank balances and the 8 percent reserve ratio where the Selic rate is earned. Banks were exempted from the extraordinary reserve requirement if their total required reserves (the sum of the required reserves on the three types of deposits) was below $\mathrm{R} \$ 100$ million.

Finally, banks were required to hold 15 percent of their time deposits in government debt securities that also paid the Selic rate. ${ }^{29}$ Banks were exempted from this requirement if their required reserves were below the $\mathrm{R} \$ 300$ million deductible, that is, if banks held less than R $\$ 2$ billion in time deposits. ${ }^{30}$ Except for an increase in the deductible on government bond holding requirement in late 2004 from $\mathrm{R} \$ 100$ million to $\mathrm{R} \$ 300$ million for reasons that will be discussed shortly, reserve requirements had not been altered since the crisis period of 2002-03.

\footnotetext{
${ }^{29}$ There does not appear to have been a constraint on the type of government securities (fixed rate, floating rate, CPI-linked) that banks could hold other than that the securities be marketable ones. Floating rate securities dropped from 60 percent in outstanding federal government marketable debt in December 2004 to about 35 percent in March 2008, reflecting the rise in the shares of fixed rate and inflation -linked bonds. There is no comparable breakdown in the type of debt held to fulfill reserve requirements.

${ }^{30}$ The government bond holding requirement offered an advantage over the cash reserve requirement that paid the Selic rate in that banks could temporarily deviate from the government bond holding requirement to manage their intra-daily liquidity needs.
} 
Although these reserve ratios are high, for many banks, effective reserve ratios have been much lower than the statutory ratios. I estimate that only 41 banks were required to hold any reserves at all in December $2007 .{ }^{31}$

Effective statutory ratios could be well below statutory ratios for several reasons, one of which is the fact that most banks are small and required reserves fall below the deductibles. The third column of Table 3a displays my estimates of total required reserves on demand deposits of small and mid-sized banks as a share of their demand deposits under the unremunerated reserve requirement on demand deposits. Small and mid-sized banks are defined in this table to exclude the top ten banks and the government banks. Small and mid-sized banks' reserves were 29 percent of their demand deposits, largely because required reserves of domestic banks tended to be lower than those of foreign banks, about $15 \frac{1}{2}$ percent of their demand deposits (third column of second row). I estimate that total required reserves of small and mid-sized banks to satisfy the government bond holding requirement on time deposits was less than 4 percent of these banks' deposits, again because required reserves of domestic banks tended to be relatively low. ${ }^{32}$

Reserve requirements also shaped banks' funding choices, and funding means that emerged in the mid-2000s enabled banks to avoid the requirements. Figure 6 plots the level of bank deposits between December 1995 and 2007 after excluding the two large federally-owned banks, whose funding practices are influenced by their social

\footnotetext{
${ }^{31}$ Calculations are available from this author upon request and were based on data described in the data appendix.

${ }^{32}$ The story on reserve holdings to satisfy the extraordinary reserve requirement was similar, albeit less striking, and is not shown here to conserve space. The reserve requirement on savings deposits is not shown because only 6 of the small and mid-sized banks offered savings deposits.
} 
obligations. ${ }^{33}$ Since at least the mid-1990s, demand and savings deposits have been far less important as a source of domestic funding than have been time deposits. This is not surprising, as high reserve ratios have made demand and savings deposits unattractive as a source of funding.

As is also seen in Figure 6, an alternative form of domestic funding that was widely referred to as repo funding grew rapidly over the 2005 to 2007 period. Although this funding means was termed repo funding, for all practical purposes, the repo was actually a time deposit substitute that was created to avoid the reserve requirement on time deposits. How banks created this particular type of repo, which involved affiliated leasing companies, is complex enough to warrant leaving the details in Appendix A. In Table 1, the fifth column displays an estimate of the amount of repo funding of large banks as of December 2007, based on footnotes to financial statements. The sketchy picture that emerges is that these repos were an important source of funding for large domestic banks. In Table 3b, one can see how the repos were used to reduce the 15 percent government bond holding requirement for large banks. When adding the estimated volume of outstanding repos of large domestic banks to their time deposits, reserves were only 7 percent of "total" time deposits.

Interviews with market participants indicate that the repos were marketed mainly to large investors—-companies, wealthy investors, and to mutual and pension funds. ${ }^{34}$

\footnotetext{
${ }^{33}$ The two large government-owned banks accounted for over half of all savings deposits, reflecting their large branch network and likely investor perception of safety, as the savings deposit is the most popular investment vehicle for small savers. In addition, these banks have substantial holdings of so-called judicial deposits, which are deposits that are held at these banks pending the outcome of legal disputes. These deposits embody an implicit subsidy to the banks because the deposits pay very low interest rates.

${ }^{34}$ There are no data available on this particular type of repo holding by mutual and pension funds. Mutual funds are regulated by the Brazilian securities and exchange commission, the CVM (Comissão de Valores Mobiliarios). A detailed breakdown of the portfolios of Brazil's 8,000 investment funds, which include both pension and mutual funds, are publically available back to 2008. A preliminary look at the portfolios
} 
There are also no data available on the yields on the repos relative to time deposits. However, judging from an October 2006 article by Valor Econômico (2006a), the repos offered relatively high returns. According to Valor, because the repos were not subject to reserve requirements, banks were also able to pay investors a return that was higher than what investors earned on bank certificates of deposit.

Repos also appear to have been as liquid an investment as time deposits. In the 2006 Valor article, the maturities of the repos were reported to have ranged from 3 to 12 months. However, Mesquita and Torós (2010a), who sat on the central bank's monetary policy board in late 2008, report that "[w]ell-established Brazilian market practice, due to years of macroeconomic turbulence and high volatility, requires that banks effectively offer short-term liquidity to their deposits, regardless of the original [stated] maturity."

If the repos were as demandable as time deposits, then all else equal, the growth of this form of funding increased banks' exposure to funding pressures, one form of liquidity risk. One market participant did state that it was market practice for the repos to be redeemable on demand regardless of their maturity. It was also rumored that that Unibanco, which was to experience a well-publicized run on its time deposits during the crisis period of 2008, also experienced a runoff in its repos. Therefore, it does appear that growth in repo funding increased banks' vulnerability to funding pressures, all else equal.

Smaller banks were viewed as more vulnerable to runs on their time deposits than were large banks in part because their lack of branch networks forced them to rely on 
mutual funds as purchasers of their CDs. Smaller banks' vulnerability was highlighted by a period of instability in late 2004 that followed the failure of a mid-sized bank (Banco Santos). Many small and mid-sized banks suffered runs (Takeda and Bader 2005) as investors fled to the perceived safety of large banks. Mutual fund investors are not covered by the formal deposit insurance scheme (which covered at that time only up to $\mathrm{R} \$ 60$ thousand per account). But also, the relatively favorable treatment of the creditors of large banks that failed during the crisis period of the late 1990s, combined with subsequent reforms that aimed to limit the size of the government safety net for banks, could have reinforced investors' perceptions that the large banks were relatively safe.

To alleviate funding pressures being experienced by small and mid-sized banks in late 2004, the central bank tripled the deductible on the reserve requirement on time deposits (from $\mathrm{R} \$ 100$ million to $\mathrm{R} \$ 300$ million). During this period of stress, several small and mid-sized banks also obtained liquidity through the use of loan portfolio sales (Takeda and Bader 2005). ${ }^{35}$ Brazilian loan portfolio sales involved sales of cash flows from a pool of loans, nearly always consumer loans (in particular, payroll and vehicle loans). In the loan portfolio sales agreements that were publicized by the local press in late 2004 and throughout much of 2005, the sellers were always small and mid-sized banks and the buyers were always large banks, both privately owned banks (domestic and foreign) and the CEF. In the agreements that were reported in the press, the buying bank committed to purchasing a particular amount each month for a period—often 3 years, judging from the data that were reported by Bader and Takeda. Loan portfolio sales subsequently continued to be an important source of liquidity for some small and mid-

\footnotetext{
${ }^{35}$ These loan portfolio sales are called vendas com coobrigação or cessões de crédito com coobrigação.
} 
sized banks prior to the crisis period of 2008. It is not clear, whether there were many new agreements after early $2005 .^{36}$

Loan portfolio sales not only provided liquidity to banks that were under funding stresses but also provided these banks with new funding. Under international accounting standards such as the IFRS (International Financial Reporting Standards), loan portfolio sales should not have been a source of new funds. In Brazil, the prevailing practice was for these sales to be made with recourse. In a loan or asset sale with recourse, the seller retains the credit risk, and therefore, the same amount of bank capital is needed to be a buffer against potential loan losses. However, under central bank regulations, there was no clear distinction between recourse and non-recourse loan and asset sales. Therefore, loan portfolios that were sold with recourse could be taken off a bank's balance sheet for the purposes of computing regulatory capital. Loan portfolio sales with recourse as a funding source therefore enabled a bank to increase its profitability by increasing its leverage. Furthermore, the entire proceeds from the loan sale could also be recorded as current earnings even though there was a risk that the selling bank would have to make good on its guarantee to repurchase the loans.

It remains unclear whether the use of loan sales with recourse to fund loan growth was widespread. However, small and mid-sized banks with an aggressive enough growth strategy had an incentive to find alternatives to time deposits, both because sooner or later their reserve requirements would exceed the deductible and because mutual funds had been proven to be fickle investors. Moreover, the fact that the Brazilian central bank in April 2007 issued for public comment a proposal to tighten capital requirements on

\footnotetext{
${ }^{36}$ Also,Takeda and Dawid 2009 report that as of mid-2008, 70 percent of loan portfolio sales were purchased by large banks, so other types of borrowers apparently became more active in this "market."
} 
loan and asset sales suggests that the practices surrounding loan sales was a major concern. ${ }^{37}$ The central bank's proposal was not approved at that time, however, apparently in the face of heavy opposition from small and mid-sized banks. ${ }^{38}$ The prevailing view appears to have been that smaller banks helped promote financial sector development goals. It has been argued, for example, that smaller banks have added to competitive pressures, driving down the cost of credit. $^{39}$

\section{2007-08}

The onset of the mortgage-related financial turmoil in mid-2007 resulted in a modest tightening in access of Brazilian borrowers to international credit markets. ${ }^{40}$ The Brazilian economy continued to expand at a brisk pace over late 2007 and the first half of 2008, supported by rapid credit growth and the still-heavy demand for commodities from emerging Asia. As can be seen in Figure 4, credit to firms grew particularly rapidly and Figure $5 \mathrm{~b}$ shows that average loan rates on loans to consumers and firms continued to fall over most of the second half of 2007. Over the first half of 2007, the central bank had reduced the Selic rate from 13.25 percent to 12 percent in several steps, and reduced the rate further to 11.25 percent in early September 2007, a record low. At its mid-October meeting, the central bank left its target for the Selic rate unchanged and it took no action

\footnotetext{
${ }^{37}$ In addition, between May 2007 and February 2008, Fitch published three reports detailing its concerns about risk management practices associated with the fledging market for consumer loan-backed securities (Bartling, Acevedo, Castro, Calp, and Kabance 2007, Bartling, Cost, and Mizrahi 2008).

38 Although no public comments were posted in response to this proposal on the central bank's website. Valor Econômico reports that "[ $\mathrm{t}$ ]here were hundreds of suggestions and complaints [on this proposal], principally from mid-sized banks, that feared the necessity of increasing capital with the new regulation." (Valor Econômico 2007).

${ }^{39}$ An editorial in Valor Econômico during the crisis in late 2008 argued that [smaller] "institutions are considered important instruments of the dissemination of credit, principally for the poorest segments of the population, played a relevant role in the population's increasing financial access [bancarização], and encouraging competition in the sector, promoting a healthy competition in the banking sector (Valor Econômico 2008f ).

40 The five-year CDS premium for Brazilian sovereign debt rose from 75 basis points in mid-2007 to about 150 basis points in February 2008 and subsequently fell to 100 basis points in mid-2008.
} 
at the December 2007 and January 2008 meetings. ${ }^{41}$ However, by late 2007, rapid credit growth and rising inflationary pressures were generating concerns that the economy was overheating.

On January 31, 2008, authorities moved to slow credit growth by announcing a tightening in capital and reserve requirements. ${ }^{42}$ The contentious issue of loan portfolio sales was addressed at a highest level, by the CMN, but the new regulation (Resolution 3533) appears identical to the one that had been proposed the previous April by the central bank. Banks needed to meet the new capital requirements by January 2009. The new rules, which as a result of several postponements will take effect in January 2012, also applied to the fledging market for asset-backed securities. ${ }^{43}$ That same day, the central bank announced what amounted to a 100 percent marginal government bond holding requirement on new repo borrowings (that is, the time deposit substitutes), the details of which are described in Appendix A. Finally, the central bank announced what amounted to a 25 percent government bond holding requirement on outstanding repo borrowings, to be phased in over a 12-month period starting in March. These measures were followed by a 250 basis point increase in the Selic rate in several steps between the central bank's April and September 2008 meetings (from 11.25 percent to 13.75 percent).

\footnotetext{
${ }^{41}$ In January 2006, monetary policy meetings went from being held on a monthly basis to being held twice per quarter.

${ }^{42}$ In early January 2008, the government increased a tax called the IOF [Imposto sobre Operações Financeiras] on loans from 1.5 percent to 3.0 percent. The motive for raising the tax was a fiscal one (see Central Bank of Brazil 2008, p. 14). Although the average loan rate on outstanding loans rose over 4 percentage points in January, credit continued to grow.

${ }^{43}$ Implementation of the new rules was subsequently postponed for a year during the financial crisis, on December 26, 2008, so that it would not take effect January 2010 (Resolution 3673). In October 2009, implementation was postponed to January 2011 (Resolution 3809). In July 2010, implementation was postponed to January 2012 (Resolution 3895).
} 
Despite these actions, over the first three quarters of 2008, non-earmarked credit grew at an annual rate of about 30 percent, owing to very rapid growth in credit to firms. ${ }^{44}$

Over the first half of 2008, there were also reports that small and mid-sized banks were facing tighter funding conditions because large banks were competing more aggressively for time deposits. ${ }^{45}$ The heated competition for time deposits appears to have owed in part to large banks attempting to unwind their repos in response to the reserve requirements that had been introduced the previous January. The fourth column of Table 4 displays growth in time deposits in the third quarter of 2008. The largest banks are listed while the smaller banks are grouped into aggregates by ownership. ${ }^{46}$ Several of the largest banks experienced particularly rapid deposit growth in the third quarter, with deposits of Banco Itaú rising 80 percent. In contrast, smaller private sector banks experienced a decline in total deposits. (The aggregate for small and mid-sized banks should be viewed with caution because it very likely masks variation among banks.)

\section{Fall of 2008: Crisis and Response}

Following the bankruptcy of Lehman Brothers on September 14, 2008, financial turmoil spread to the emerging market economies. The collapse in capital flows to emerging market economies has been widely documented (see Blanchard, Das, and

\footnotetext{
${ }^{44}$ Banks appear to have expected the reserve requirement to be imposed only on new funding, as the fact that the reserve requirement had not been introduced earlier had apparently been widely interpreted as a sign of a tacit approval by the central bank (Valor Econômico 2008a).

${ }^{45}$ Most time deposits were linked to the CDI rate, which is an overnight rate that usually moves in tandem with the Selic rate. CD rates are typically expressed as a percentage of the CDI rate. In May 2008, Valor Econômico (2008c) reported that the average cost of funding for large banks rose from 101 percent of the $\mathrm{CDI}$ rate to 105 percent of the CDI rate because large banks were competing more aggressively for funding.

${ }^{46}$ ABN Amro was acquired by Santander in mid-2008. Nossa Caixa Nosso Banco (NCNB), the state bank of São Paulo, became the tenth-ranked bank.
} 
Faruquee 2010). Brazilian banks experienced funding pressures in both dollars and in domestic currency. Here, I focus on the funding pressures in local currency that Brazilian banks faced and how the central bank altered reserve requirements in an attempt to meet a liquidity provision goal.

Funding pressures appeared to peak in mid-October. According to a late 2009 interview with then-central bank director of monetary policy, Mario Torós, over the week of October 6-10, deposit withdrawals were between $\mathrm{R} \$ 30$ billion and $\mathrm{R} \$ 40$ billion (Romero and Ribeiro 2009), in other words, between $5 \frac{1}{2}$ percent and 71/2 percent of total time deposits as of the end of September.

The media typically characterized banks' funding problems as a flight-to-safety from small banks to large banks. Central bank data on time deposits are most readily available on a quarterly basis. As can be seen in Table 4, government-owned Banco do Brasil as well as Itaú and Bradesco did experience sizeable inflows of time deposits over the fourth quarter of 2008. Deposits of small and mid-sized banks as a group, shown in the bottom panel, declined sharply over the fourth quarter, particularly those of the domestically owned banks. However, Unibanco and Votorantim also suffered serious funding problems. In addition, Banco Safra, one of the largest domestic banks, experienced funding problems that were either less severe or more short-lived.

Banco Votorantim's deposit outflows were attributed to its affiliation by ownership with companies that had reported large losses on uncovered foreign currency positions under over-the-counter derivatives. ${ }^{47}$ Banks had been the counterparties in

\footnotetext{
${ }^{47}$ On September 26, 2008, Aracruz Cellulose, the world's largest pulp and paper producer, announced large probable losses on currency derivatives. Aracruz was a member of the Votorantim Group. Another member of that group, Votorantim Celulose e Papel (VCP), announced heavy losses on October 10.
} 
these arrangements. The complex nature of these derivatives made it very difficult to assess the size of the probable losses. The bank's shared identity with the non-financial firms in the Votorantim Group and the opacity of financial relationships within the conglomerate made the bank vulnerable to adverse reputational spillovers. It was difficult for investors to separate the health of the bank from the health of the affiliated firms. For Banco Safra, a similar reputational spillover appears to have resulted in some funding stresses.

These derivatives had been employed by many companies, judging from the media, which over much of October speculated about how widespread the foreign currency-related losses could be. The financial turmoil effectively constrained monetary policy, as the central bank did not reduce the Selic rate over the fall of 2008 and intervened heavily to support the currency. The concern was that an interest rate cut would result in an adverse feedback loop by feeding further exchange rate depreciation, leading to further losses on firms' currency derivative positions and consequently lowering their net worth. Deteriorating corporate sector health also potentially put the health of banks at risk. The central bank did not begin to reduce the Selic rate until its late January 2009 meeting.

In late October, Unibanco suffered heavy runs that were accompanied by media reports that the bank had also been heavily exposed to companies that suffered losses on their currency derivatives (denied by the bank's management). On November 3, 2008, Unibanco and Banco Itaú announced their merger, and that announcement appears to have resulted in a quick improvement in Unibanco's funding conditions. 


\section{Changes in Reserve Requirements}

In the fall of 2008, banks that were under funding stresses avoided the central bank's discount window for fear of being stigmatized, despite a measure that was enacted by the Lula government in early October (Provisional Measure 442) to improve banks' access to the discount window. At that time, fiscal and legal issues and ultimately, political constraints limited the central bank's ability to pursue more aggressive measures to exercise a lender of last resort role. According to Mesquita and Torós (2010b), controversy over the central bank's lender of last resort powers centers over the question of whether central bank direct assistance to financial institutions is regarded as involving the use of public money. If public money is involved, under the Fiscal Responsibility Law of 2001 (the Brazilian congress's main response to the banking crisis of the 1990s), the assistance operation would require "specific laws." In addition, the central bank is not legally independent and central bank officials are legally responsible for any actions that they take in while in office for up to five years after leaving office. Former central bank officials had faced political and legal troubles in the recent past (O Globo 1999, Reuters News 2000, and Jornal do Comércio 2007). Judging from interviews with former central bank officials and informed observers, the threat of legal action continues to be taken seriously.

By contrast, since its creation in 1964, the Brazilian central bank has had a remarkable amount of flexibility over reserve requirements. The central bank does not only have the authority to set the reserve ratio and decide whether or not to pay interest on required reserves. The central bank also has the authority to determine the type of asset that must be held to satisfy the requirement, including cash, government debt, or 
assets that earn below-market rates. This statutory provision essentially endows the central bank with the authority to institute the cross-subsidy scheme that I describe below. These statutory powers are detailed in Appendix B.

As shown by the first column of Table 5, at the end of September 2008, the banking system held an estimated $\mathrm{R} \$ 172$ billion in reserve balances at the central bank. In addition, banks also held government securities totaling $\mathrm{R} \$ 100$ billion on their balance sheets to meet the government bond holding requirement. The total, $\mathrm{R} \$ 272$ billion, was referred to by central bank officials as the "arsenal of liquidity" that could be released to alleviate funding pressures. ${ }^{48}$ Although the banking sector as a whole also held over $\mathrm{R} \$ 300$ billion in government securities in the form of reverse repurchase agreements (Table 5, line B), this liquidity was concentrated in a relatively small number of banks. ${ }^{49}$ Reserve requirements became the main liquidity provision tool of the central bank. Changes in the reserve requirements were aimed at meeting the liquidity needs of particular banks. As was recounted by Mario Torós,

We knew the cash [flow] situation of the banks before they themselves closed their [vaults] ... [With] the liquidity gaps in the system identified, entering the scene was the head of the department of banking operations and payments system ... with his computer that simulated how much money was liberated and which banks were the beneficiaries with the measures of the cuts in compulsory deposits. We all stayed in the room, around the computer, until deciding which measure had the desired effect (Romero and Ribeiro 2009).

\footnotetext{
48 For example, on October 9, 2008, about a week after the central bank had begun to relax reserve requirements, Central Bank President Henrique Meirelles stated that with the measures takes so far, "[w]e only liberated a little more than 10 percent of the [reserve requirements] of the banks," and that there was R\$200 billion in compulsory deposits that could still be released (O Globo 2008). See also Romero (2008).

49 The central bank's principal operating tool for monetary policy is the repo/reverse repo. The central bank had been conducting sizeable amounts of reverse repo operations between 2006 and 2008 to sterilize its accumulation of international reserves under intervention operations to counter upward pressures on the real.
} 
Brazilian officials confronted two challenges in the use of reserve requirements as a liquidity provision tool. First, changes in reserve requirements typically involve an implementation lag. Timeliness in meeting liquidity needs can be critical for a bank that is confronting a run. ${ }^{50}$ The main challenge facing authorities, however, was that the lion's share of the \$R272 billion in reserves was held by large banks. As seen in the second column of Table 5 , an estimated $\mathrm{R} \$ 255$ billion in reserves was held by the country's 7 largest banks by assets (Banco do Brasil, Itaú, Bradesco, Santander, CEF, Unibanco, HSBC) and by Nossa Caixa Nosso Banco (NCNB), the state bank of São Paulo, which was then ranked 10th. Given this concentration of liquid assets, there needed to be a mechanism for redistributing the liquidity from large banks (other than from Unibanco, Votorantim, and Safra, which were under funding stress) to smaller banks. In the rest of this section, I detail how the central bank altered reserve requirements in response to the very difficult circumstances that it faced.

Tables $6 \mathrm{a}$ to $6 \mathrm{c}$ detail several of the important changes in reserve requirements in the fall of 2008. The first column shows the date that the change was announced while the second column shows the date that the change took effect. The ratios shown by the red italics are the reserve ratios that were implied by the changes in the requirements, as these ratios were not always stated explicitly.

As can be seen in the last column of the tables, the deductibles were raised several times. By my estimates, the October 13 increase in the deductible on the cash reserve requirement that paid the Selic rate (under Table $6 \mathrm{~b}$ ) took effect that same day, and

\footnotetext{
${ }^{50}$ Brazil uses a lagged requirements system. Under a lagged reserve requirements system, required reserves are computed based on the average deposit levels that prevail over an earlier period. Judging from an examination of several Brazilian central bank regulations, there was a one- to two-week lag between the day of a change in the requirement and when the requirement would begin to take effect.
} 
combined with the decline in reserve ratios on demand and time deposits that day released over $\mathrm{R} \$ 20$ billion to the banking system. An estimated $\mathrm{R} \$ 15$ billion was released on October 17 as a result of another rise in a deductible. Assuming that deposit levels of most banks had held to their end-September levels, I estimate as a result of the changes in reserve requirements, likely only nine banks still needed to fulfill any reserve requirements (that is, they were not exempted from the requirements) by October 17: the eight largest banks that were listed in Table 3 and Nossa Caixa Nosso Banco (NCNB), the state bank of São Paulo. Very likely, Votorantim by then had likely suffered such a sufficiently heavy run on its time deposits that the bank's required reserves had fallen to zero.

While these steps helped meet banks' liquidity needs, they were not enough, prompting the central bank to alter reserve requirements with the aim of inducing redistribution from liquidity-rich large banks to liquidity-constrained banks. The central bank had first attempted to induce this distribution voluntarily on October 2, 2008. At that time, it announced that, "with the objective of improving the distribution of resources in the National Financial System," banks could essentially exchange government securities that they had been holding to meet the 15 percent government bond holding requirement on time deposits for loan portfolios of small banks. Up to 40 percent of the 15 percent reserve requirement could be exchanged for loan portfolios. Because this measure was voluntary, in the Tables $5 \mathrm{a}$ to $5 \mathrm{c}$, there is no change in the reserve ratio, only a rise in the deductible. (Refer to the second row of Table 6c.) On October 13, the central bank raised the share of government bonds that could be exchanged from 40 to 70 percent. Over much of the rest of October, the central bank attempted to make the 
terms of the funding by large banks to other banks more attractive by broadening the class of assets of smaller banks that relatively large banks could acquire (see, for example, Leme 2008).

Initially, banks were eligible for funding from large banks if their regulatory capital (Património de Referência Level I or PR1, which appears to be Tier I capital under Basel II) did not exceed R $\$ 2.5$ billion as of the end of August 2008. On October 13, the central bank effectively allowed larger banks to be eligible for funding by raising the ceiling to a PR1 of R $\$ 7$ billion, with the new ceiling taking effect on October 17. Bank-level data on regulatory capital is not published by the central bank, but many banks disclose their PR1 in quarterly financial statements that can be found on the Web. Votorantim's financial statements reported PR1 levels of $\mathrm{R} \$ 6.3$ billion and $\mathrm{R} \$ 6.4$ billion at the end of June and December 2008. Alternatively, the book value of capital (under "net worth" in central bank data) appears to be a good proxy for PR1. There were 88 small banks with book net worth below $\mathrm{R} \$ 2.5$ billion. There were nine banks with book net worth between $\mathrm{R} \$ 2.5$ billion and $\mathrm{R} \$ 7$ billion, including HSBC, Votorantim, and Safra. That left 6 banks as "large." (The number of banks had by the third quarter had increased from 101 to 103.)

This attempt to redistribute liquidity from large banks to smaller banks (termed "small and mid-sized banks" at that time) could not have been effective in the fall of 2008. At that time, the demand for liquid assets was extraordinarily high in Brazil as it was elsewhere in the world, likely in part because banks were uncertain about their own liquidity needs. In addition, uncertainty about the extent of losses from currency derivatives must have fueled concerns about counter-party risk. Press reports and other 
evidence support this interpretation. In mid-October, media reports indicated that a number of banks that were under funding pressures were forced to sell with recourse their loan portfolios at a sizeable discount in mid-October (Valor Online 2008, Pereira 2008, Folha de São Paulo 2008a). On October 23, Renato Oliva, president of the Association of Brazilian Banks (ABBC) which represents small and mid-sized banks stated that "[1]arge institutions still have not responded to the stimulus (measures) of the government. The acquisition of [loan] portfolios is very slow and represents a small amount" (O Estado de São Paulo 2008). The media also noted that aggregate holdings by the banking sector of government bonds under reverse repurchase agreements with the central bank climbed noticeably.

Media sources also reported that President Lula and government officials expressed dissatisfaction about the slow pace of loan portfolio purchases by large banks. Allegedly, the government considered reducing the interest earned by banks on their required reserves (D'Amorim 2008). It was even suggested that the government might take a particular stand on still-unresolved lawsuits against banks by depositors who had suffered large losses during the anti-inflation plans of the late 1980s and early 1990s (Valor Econômico 2008e).$^{51}$

On October 30, the central bank took a more aggressive step to induce the redistribution of liquidity. Banks would need to exchange 70 percent of the reserves held under the government bond holding requirement for zero-interest bearing reserve accounts at the central bank. In effect, for large banks, a 10.5 percent non-remunerated reserve ratio was introduced -10.5 percent is 70 percent of the 15 percent reserve ratio-

\footnotetext{
${ }^{51}$ According to the Valor article, by some estimates, the banking sector faced a potential liability that was as high as R $\$ 120$ billion. To put that figure into perspective, the banking sector's after-tax profits totaled about $\mathrm{R} \$ 10$ billion in the third quarter of 2008 .
} 
as is noted in Table 6a in red italics (in red italics because this reserve ratio was not explicit). ${ }^{52}$ However, banks that were subject to the new requirement had the alternative of providing funding to the list of eligible banks. The changes were to take effect on November 14, 2008. Hence, in late October 2008, the reserve requirement framework became a cross-subsidization scheme under which large banks were taxed to subsidize small banks.

To ameliorate the burden of this implicit tax, the central bank also allowed large banks to acquire to unsecured overnight interbank deposits (the CDIs). An advantage of the CDIs is that they did not require the "purchasing bank" to evaluate the selling bank's loan portfolio, which was reportedly a very time-consuming task. In addition, the CDIs appear to have been far more liquid in the sense that large banks could have simply refused to roll over what amounted to a one-day loan. ${ }^{53}$

Figure 7 attempts to depict graphically the complex changes in the reserve requirements for large banks. The top panel displays the quasi-statutory reserve ratios on zero- or well below-market interest bearing deposits. The caveat is that the graphs are constructed under the assumption that the quasi-statutory reserve ratios were binding, that is, that large banks would have preferred to hold government bonds to a claim on a small or mid-sized bank. The quasi-statutory reserve ratio was reduced from 10.5 to 9 percent in mid-December 2008 (taking effect in early January 2009), as funding stresses had eased, and was reduced further in October 2009. The bottom panel of Figure 7 is the sum

\footnotetext{
${ }^{52}$ Subtracting the then-R $\$ 2$ billion deductible from required reserves lowered the banks' effective reserve ratio, but for the largest four banks and for the CEF, the effective reserve ratio was still nearly as high. Estimates are available from the author upon request.

${ }^{53}$ Circular 3,417, which introduced the de facto tax, did not set a minimum term for these CDIs (see Article 3 Section 8).
} 
of the effective reserve ratios on time deposits that enabled large banks to earn the Selic rate.

Overall, the attempt to redistribute reserves from large banks to smaller banks via the reserve requirement mechanism does not appear to have been as successful as has been asserted. Consequently, other means of alleviating funding pressures were used in late 2008, and these means involved government banks and the deposit insurance authority, as is briefly discussed below.

\section{Official and Quasi-official Support Mechanisms}

\section{a. The government depository institutions}

Over the month of October, Banco do Brasil and CEF officials were quoted in several media reports as being involved in the process of providing funds to eligible banks. Although the responses of Banco do Brasil and CEF could have arguably been for business reasons, comments from Finance Minister Guido Mantega make it clear that the two large government banks and the BNDES (the government development bank) were expected to provide liquidity support to banks in need.

On October 21, 2008, the Lula government enacted a measure (MP 443) that authorized Banco do Brasil and the CEF to take equity stakes in other banks. ${ }^{54}$ Finance Minister Mantega justified this measure as a means for providing liquidity to banks in need:

... [I]n light of the current situation of the lack of liquidity in the Brazilian financial market, we are taking this measure because it goes in the direction of facilitating liquidity and permits that some Brazilian financial institutions that don't have liquidity have this

\footnotetext{
${ }^{54}$ After extensive debate, in mid-November, congress approved the measure but with an amendment so that the measure would expire after June 2011, although the executive may extend the measure for another twelve months.
} 
alternative of a ... [unintelligible] or a merger or even a transfer of ownership [alienação] to a public financial institution. ${ }^{55}$

However, taking an equity stake in a bank not only injects liquidity but also injects capital into the acquired bank. Banco do Brasil's purchase of a 49.9 percent stake in Banco Votorantim was announced in early January 2009 after several weeks of negotiations, judging from media reports. Banco do Brasil was also rumored to have already provided $\mathrm{R} \$ 5.8$ billion in funding to Banco Votorantim as well as funding to two other banks (Valor Econômico 2008g). Banco do Brasil was also reported to have provided other forms of financial support to banks and the non-financial firms at the height of the crisis (Ribeiro 2009).

\section{b. The BNDES}

On November 25, 2008, the central bank changed reserve requirements, providing large banks with another alternative to the 10.5 percent unremunerated reserve requirement on time deposits. Instead of providing funding to an eligible bank, large banks could purchase CDIs issued by the government development bank, the BNDES. The BNDES could issue up to R $\$ 6$ billion in CDIs with maturities of 6 to 18 months. In a press release that was posted on its website, the central bank stated that the measure "complements the actions of the central bank in the sense of improving the distribution of resources of the ... [financial system] ... and the credit conditions for small and medium sized firms." Lending to the BNDES was akin to lending to the government. The BNDES' interbank liabilities expanded from zero in September 2008 to $\mathrm{R} \$ 5.3$ billion the following December.

\footnotetext{
${ }^{55}$ See Mantega and Meirelles (2008).
} 
It appears that the BNDES channeled the funds that it received from large banks to the non-financial sector. Of course, it is possible that the BNDES' loans to the nonfinancial sector supported banks indirectly if it provided funding to firms (or their affiliates) that were experiencing cash flow problems. To the extent that BNDES funding could alleviate a firm's cash flow problems, other creditors of the firm (including banks) were more likely to be repaid, all else equal.

\section{c. The Deposit Insurance Authority}

Liquidity provision to the smaller banks in need also involved the Fundo Garantidor de Crédito (FGC), the deposit insurance authority. Although the FGC is formally a private non-profit organization that is funded by member banks, its close relationship with the government makes it more akin to a government-sponsored entity. The FGC was created by the CMN in 1995, the midst of the banking crisis. Moreover, the CMN approves the FGC's statutes, which require all banks to join the FGC, and sets the limit on deposit insurance.

Prior to the crisis of 2008, the FGC's responsibilities largely involved collecting insurance premiums and making payouts to depositors of failed banks. Even as of late 2008, the FGC had only two full-time employees, as the task of making the payouts to depositors was outsourced. The deposit insurance fund is small and, since 2004, the entity's statutes permitted it to provide a relatively small amount of funding to member banks (20 percent of its equity). As of October 9, 2008, the FGC had purchased $\mathrm{R} \$ 700$ million in loan portfolios of smaller banks, largely consisting of consumer loans. FGC Executive Director Antonio Carlos Bueno stated that the fund would conduct more 
such operations. At that time, however, the lending capacity of the FGC was only $\mathrm{R} \$ 2.5$ billion. $^{56}$

During the crisis, two steps were taken by Brazilian authorities to increase the FGC's lending capacity. First, in late October, a change in reserve requirements enabled large banks to devote a portion of the reserves used to fulfill the unremunerated reserve requirement on demand deposits to the pre-payment of their deposit insurance premiums, up to 60 months in advance (Circular 3416, October 24, 2008, which took effect that same day). The FGC received an extra $\mathrm{R} \$ 5.4$ billion in advance premium payments as a result. Second, on December 17, 2008, the FGC's statutes were amended by the CMN so that the institution could devote up to 50 percent of its equity to the purchase of loan portfolios and asset-backed securities called FIDCs (Fundos de Investimento em Direitos Creditórios). The two steps increased the FGC's available resources for such operations to $\mathrm{R} \$ 9$ billion.

Press reports asserted that the FGC's asset purchases in late 2008 were an important source of liquidity for small banks at that time. This is even though, as of early 2009 , only R $\$ 4$ billion of the $\$ R 9$ billion in lending capacity of the FGC had been used (Carvalho 2009a, 2009b) to provide funding to 25 small banks. One market observer opined that the popularity of the funding reflected the use of an auction mechanism to allocate funding, which removed stigma. However, because responsibility for conducting the auctions was outsourced to Banco Itaú and Bradesco, it is not clear how complete anonymity of the borrowers could have accomplished. Funding from the FGC could have still been attractive relative to the cost of obtaining credit from other banks for another reason. When large banks pre-paid their deposit insurance premiums, the

\footnotetext{
56 See Carvalho (2008), accessed from the FGC's website.
} 
foregone interest on required reserves that had been previously absorbed by the central bank in the form of seigniorage revenue could have been passed on to the FGC's borrowers.

\section{Conclusion}

In this paper, I examine the Brazilian experience with reserve requirements as a case study that can highlight the obstacles policymakers may face in their efforts to limit banks' exposure to liquidity risk. The Brazilian experiences in the years that preceded the global financial crisis highlight the importance of considering how a liquidity requirement could induce changes in bank behavior that have undesirable consequences. High reserve requirements induced banks to devise alternative funding means, large banks by introducing a time deposit substitute and smaller banks by relying more on loan portfolio sales. Reserve requirements also did not ensure adequate liquidity for small banks because they had been exempted from the requirements. In hindsight, if tighter capital requirements on loan and asset sales may have slowed the development of consumer lending market in Brazil, tighter capital and reserve requirements would have also made smaller banks less prone to runs. And the fact that most deposits have been essentially redeemable upon demand - a legacy of a history of macroeconomic and banking instability—made banks more susceptible to funding pressures than otherwise would be the case.

During the fall of 2008, reserve requirements also could not have successfully achieved a liquidity provision goal because liquidity was concentrated in the largest 
banks, which hoarded liquidity. ${ }^{57}$ As a result of this predicament and constraints on the central banks, government entities essentially assumed lender of next-to-last resort roles.

Subsequent events also seem to raise questions about whether the crisis-period responses alleviated all of the funding stresses in a lasting way. When, in the spring of 2009, funding conditions for small and mid-sized banks had not improved sufficiently, a generous deposit guarantee for these banks was created that provides a full guarantee from the FGC up to $\mathrm{R} \$ 20$ million. ${ }^{58}$ This measure essentially extended deposit insurance to the mutual funds, the main holders of CDs of small and mid-sized banks. Formal deposit insurance at that time was limited to $\mathrm{R} \$ 60$ thousand per account holder (raised to R\$70 thousand in December 2010).

Although funding conditions for these banks subsequently improved following the institution of the guarantee, in late 2010, stresses reappeared following the collapse of a mid-sized bank, Banco Panamericano, despite the rescue that involved the FGC and the CEF. ${ }^{59}$ Reportedly, revelations of mismanagement at Panamericano, including fraudulent loan portfolio sales transactions, led large banks and other buyers of these assets to halt further purchases to re-evaluate the risks that they were taking. This would seem to have amounted to a run on the loan portfolios. Brazilian authorities have responded with measures that look very promising. These developments have prompted authorities to tighten capital requirements and take other measures. Most recently, for

\footnotetext{
${ }^{57}$ As noted by Goodfriend and Hargraves (1983), recurring banking panics in the United States in the late 1800 s made it clear that reserve requirements did not achieve their liquidity provision goal. That goal was delegated to the Federal Reserve Banks upon the creation of the Federal Reserve System in 1913. ${ }^{58}$ These deposits were subject to a limit of $\mathrm{R} \$ 5$ billion per bank. In May 2009, a minimum maturity of 6 months was established, and the minimum was raised to 12 months the following September.

${ }^{59}$ The CEF, which had already taken a 49 percent stake in the bank in mid-2009, took control over Panamericano's management. Banco Panamericano is a regarded as a mid-sized bank but it has been a large provider of consumer credit. Gabriel Jorge Ferreira, the president of the board of directors of the FGC stated at the time of the rescue that the liquidation of the bank would undermine confidence in other small and mid-sized institutions. .
} 
example, there has been increased support for a reform that will enable banks to obtain the credit histories of potential borrowers - which has so far been impossible to do because of consumer protection concerns.

A careful analysis of the potential medium- and longer-term consequences of the crisis and post crisis responses is needed, particularly since both fiscal and financial stability are pre-conditions for a successful inflation targeting regime (Mishkin 2004). Such analysis would also inform the often contentious debate in Brazil over the appropriateness of central bank independence, the scope of the government safety net for banks, and the central bank's role as a lender of last resort. 


\section{Appendix A: Reserve Requirements and Repo Funding 2005-2008}

Brazilian banks and other financial institutions often are members of a conglomerate (defined as a banking conglomerate on central bank regulation). To create the repo, the leasing company would sell a debenture to an affiliated financial institution (see Figure A1). ${ }^{60}$ The debentures were medium- to long-term bonds that were issued domestically. The proceeds from this "sale" would then be deposited with the leasing company's affiliate in the form of short-term interbank deposit certificates that are called CDIs (certificados de depósito interfinanceiro). The CDIs would net out in consolidated financial statements that these conglomerates are required to submit to the central bank, but the affiliate gained an asset, a debenture that it could then sell to investors under repurchase agreements. The proceeds of the repo sale could be used to make new loans. This funding strategy was pursued by the country's largest private sector banks (including some foreign banks) as well as some mid-sized banks.

In Figure 6, the outstanding level of repo borrowing was estimated from data on public offerings of debentures by leasing companies that were registered with the Brazilian securities and exchange commission, the CVM (Comissão de Valores Mobiliarios). The lion's share of the debenture issues were registered with the CVM. ${ }^{61}$ The CVM's website listed 43 public offerings of leasing company debentures over the January 2005-January 2008 period and the median maturity of the offerings was about

\footnotetext{
${ }^{60}$ The leasing company debentures were subordinated obligations. The banking analysts interviewed did not know whether the lead bank of the banking conglomerate was legally obligated to guarantee the debentures. They stated that for reputational reasons, the lead bank would be expected to guarantee the debentures, even if it might not be legally obligated to do so.

${ }^{61}$ It was common for the registration to occur several months after the date of the issue. Therefore, it appears that the leasing company debentures were not actually intended to be sold to the public.
} 
15 years. $^{62}$ My estimate of $\mathrm{R} \$ 145$ billion in outstanding leasing company debentures is somewhat near the $\mathrm{R} \$ 160$ billion estimate that the Brazilian central bank provided for the stock of leasing company CDIs as of November 2007 (January 31, 2008 central bank press release). Some debenture issues were private placements, which likely accounts for the difference between the two estimates.

On January 31, 2008, the Brazilian central bank introduced a 100 percent reserve requirement on new leasing company purchases of CDIs with affiliates (circular 3375). In addition, the central bank introduced a 25 percent reserve requirement on outstanding leasing company CDIs that were deposited with affiliates. These reserve requirements were to be fulfilled by holding marketable government securities that earn the Selic rate. The reserve requirement was to be phased in over a twelve-month period, rising to 5 percent in mid-March, 10 percent in mid-May, 15 percent in mid-September, 20 percent in mid-November, and to 25 percent in mid-January 2009. On September 24, 2008, the November 2008 and January 2009 increases were postponed by two months. On December 2008, leasing company CDIs became subject to the reserve requirements that applied to time deposits.

\footnotetext{
${ }^{62}$ ItaúSeg, the insurance company subsidiary of Banco Itaú, listed two public offerings of two- and threeyear debentures, but the amounts issued were relatively small.
} 
Figure A1. Brazilian bank repo borrowing

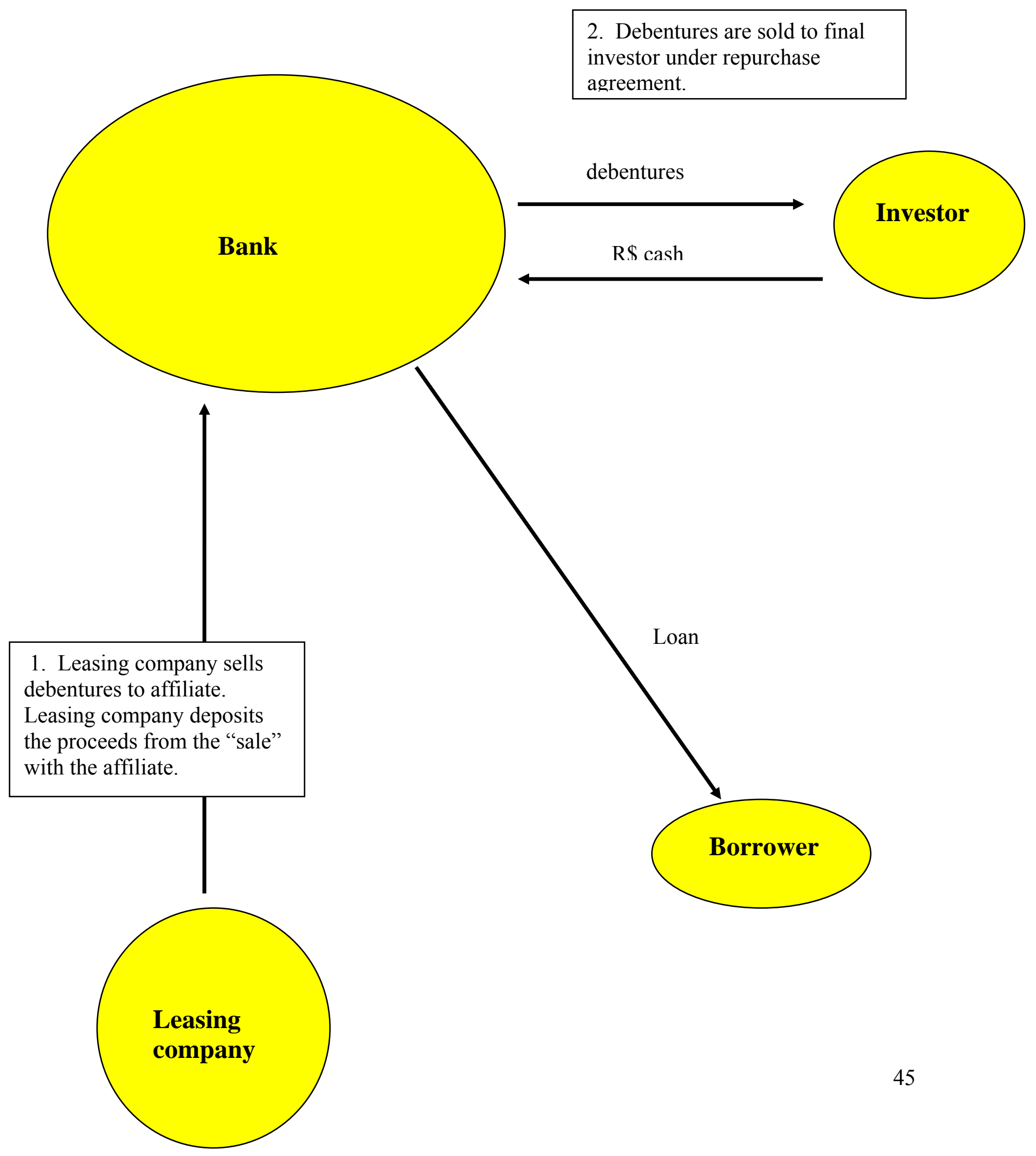




\section{Appendix B: The Brazilian Central Bank's Authority on Reserve Requirements}

The central bank's powers to set reserve requirements (recolhimento) are established by Law 4595 , the statute that authorized the creation of the central bank. This authority is set under the limits as prescribed by Article 10 (amended in 1989 under Article 19 of Law 7730). The reserve requirements on savings deposits are determined by the National Monetary Council, the CMN (Mesquita and Torós 2010).

The central bank may determine the reserve ratio of up to 100 percent on demand (sight) deposits and up to 60 percent on other financial instruments (títulos contabéis) of financial institutions. The central bank has the latitude to determine whether reserve requirements bear interest or not. Reserve requirements can be satisfied in the form of cash or government debt. In particular, Article 19 states that compulsory requirement may be satisfied "in the form of ....Letters of Obligation of the National Treasury (a government bond that is no longer issued) ..., the purchase of federal government securities (títulos), or in the form of cash requirements, in both cases to be delivered to the Central Bank of Brazil in the form and under the conditions that it determines...”

The statutory provision that enables the central bank to operate cross-subsidy schemes is Section IIIb of Article 19, which states that the central bank can "determine percentages (of the reserve requirement) that will not be collected as long as these funds have been re-invested in financings to agriculture, under favorable interest rates and under other conditions that the central bank can determine." (Italics are added for emphasis.) 


\section{Data Appendix}

The bank-level data that used in this paper were drawn from primarily from the quarterly financial statements that are available on the Central Bank of Brazil's website (50 largest banks, www.bcb.gov.br). The banking data were drawn from the Consolidated I segment, which comprises the institutions that engage in commercial banking as one of their services. The decision to include only those banks that were in commercial banking resulted in the exclusion of about 30 financial institutions that specialize in auto or consumer durables financing and institutions that specialized in investment banking. ${ }^{63}$ Unibanco's deposits in 2008 were drawn from monthly financial statements that are posted on the central bank's website. These data appear to be based on financial statements that are not as highly consolidated as the 50 largest banks data, and hence were less than ideal, but appeared to be the only data available that covered the fourth quarter of 2008. Financial statements of the largest banks were used to obtain the bank-level data on repos (the time deposit substitutes).

\footnotetext{
${ }^{63}$ Roughly half of the excluded financial institutions were foreign-owned. By assets, the median size was R \$1 billion. The largest of these institutions, Volkswagon, had assets that totaled R \$12 billion in September 2008. Adding these banks to the study would not have altered the main points of this paper.
} 


\section{References}

D'Amorim, Sheila (2008). "Governo ameaça reduzir remuneração a bancos"

[Government threatens to reduce remuneration of banks], FolhaNews, October 20.

Baer, Werner, and Nader Nazmi (2000), Privatization and restructuring of banks in Brazil, The Quarterly Review of Economics and Finance, 40: pp. 3-24.

Bartling, Jayme, Matias Acevedo, José Castro, Gláucia Calp, and Greg Kabance (2007). "Excess Spread: Friend or Foe? A Look at Prepayment Risk in Brazil," FitchRatings, May 11.

, Bernardo Cost, and Ely Mizrahi (2008). Underestimated Risks in Brazilian Investment Funds Backed by Payroll Deductible Loans, FitchRatings, February 26.

Barros, Guilherme, and Vinicius Torres Freire (2008). "BC dará novo socorro a bancos pequenos" [Central Bank will give new aid to banks],Folha de São Paulo, December 13.

Basel Committee on Banking Supervision (BCBS) (2009). International framework for liquidity risk measurement, standards and monitoring, Consultative Document, Bank for International Settlements (BIS), December.

(2010). Basel III: International framework for liquidity risk measurement, standards, and monitoring. December.

Bernanke, Ben S (2010). Central Bank Independence, Transparency, and Accountability. Speech at the Institute for Monetary and Economic Studies International Conference, Bank of Japan, Tokyo, Japan, May 25.

Bevilaqua, Afonso, Mário Mesquita, and André Minella (2007). Brazil: Taming Inflation Expectations. Central Bank of Brazil Working Paper No. 129, January.

Blanchard, Olivier, Mitali Das, and Hamid Faruquee (2010). The initial impact of the crisis on emerging market countries, mimeo, January.

Brunnermaier, Markus, and Motohiro Yogo (2009). A Note on Liquidity Risk Management. American Economic Review, May, pp. 578-83.

, Gorton, Gary, and Arvind Krishnamurthy (2010). "Liquidity Mismatch," work in progress. www.kellogg.northwestern.edu/faculty/drisharvind/papers/.

Central Bank of Brazil (2008). Relatório de Economia Bancária e Crédito [Report on bank economy and credit]. Available on www.bacen.com.br (in Portuguese). 
Cardoso, Eliana (2003). Seigniorage, Reserve Requirements and Bank Spreads in Brazil, in Taxation of Financial Intermediation: Theory and Practice for Emerging Economies, Edited by Patrick Honohan.

Carvalho, Fabia, and Cynthia Azevedo (2008). The incidence of reserve requirements in Brazil: Do bank stockholders bear the burden?, Journal of Applied Economics, May 2008,v. 11, iss. 1 pp. 61-80.

Carvalho, Maria Cristina (2008). "FGC comprou 4 carteiras de crédito de bancos" [FGC bought 4 bank loan portfolios], Valor Econômico, October 9.

(2009a), "FGC estimula expansão de crédito" [FGC stimulates credit expansion], Valor Econômico, March 6.

(2009b), "FGC amplia atuação e banca novas operações de crédito" [FGC expands operations and intends to do new credit operations], Valor Econômico, March 9.

Catao, Luis, Eduardo Cavallo, Alejandro Izquierdo, Andrew Powell, and Ernesto Talvi (2008). All That Glitters May Not Be Gold: Assessing Latin America's Recent Macroeconomic Performance, Research Department, Inter-American Development Bank, April.

Coelho, Christiano Arrigoni, Bruno Funchal, and Joao Manuel Pinho de Mello (2010). The Brazilian Payroll Lending Experiment, PUC Working Paper No. 573, April.

Colitt, Raymond (2004). "Brazil to push on with controversial proposal for central bank autonomy," Financial Times, July 16. , and Cesar Bianconi (2006). "Interview: Brazil minister says Lula to keep budget target," Reuters News, August 23.

Cotias, Adriana (2011). "Para centrais, quem atua em correspondente é considerado bancário" [For labor unions, whoever acts as a correspondent is considered a banker],Valor Econômico, January 20.

Committee on the Global Financial System (CGFS) (2010). Macroprudential instruments and frameworks: a stocktaking of issues and experiences, CGFS Paper No 38, May.

Dow Jones (2005). "Brazil House Government Whip Says Central Bank Autonomy Not Priority," September 30.

The Economist (2004), "Scandal—and Success - Brazil's central bank," July 31.

Espinosa, Marco (1995). Multiple Reserve Requirements, Journal of Money, Credit, and Banking, Vol 27, No. 3, August, pp. 762-776. 
O Estado de São Paulo (2008), "Estimulo à aquisição de carteiras falhou" (Stimulus to the acquisition of [loan] portfolios failed), Oct 23.

Feinman, Joshua (1993). Reserve Requirements: History, Current Practice, and Potential Reform, Federal Reserve Bulletin, Board of Governors of the Federal Reserve System, June.

Fernandes, Nalu (2009). "Meirelles: compulsório ajudou o Pais” [Meirelles: compulsory requirements helped the country], Jornal do Commério do Rio de Janeiro, August 26.

Folha de São Paulo (2008a). "Banco "devolve" compulsório ao BC" [Bank "returns" required reserves to the Central Bank], October 15.

(2008b). "Bancos públicos irão suprir o mercado" [Public banks will supply the market], October 19.

Fry, Maxwell (1995). Money, Interest, and Banking in Economic Development, Johns Hopkins University Press.

O Globo (1999). "Os depoimentos de Maria do Socorro e de Teresa Cristina desmontaram a rede de mistérios que parecia cercar a CPI dos Bancos," [Maria do Socorro's and Teresa Cristina's testimonies broke down a mysterious web that seemed to surround congressional banking committee investigation], May 5.

(2008). “As armas anticrise" [Anti-crisis weapons], October 10.

Goldfajn, Ilan, Katherine Hennings, and Helio Mori (2003). Brazil's Financial System: Resilience to Shocks, No Currency Substitution, But Struggling to Promote Growth, Central Bank Working Paper No. 75.

Goodfriend, Marvin, and Hargraves, Monica (1983). A Historical Assessment of the Rationales and Functions of Reserve Requirements, Federal Reserve Bank of Richmond.

Hausmann, Ricardo (2008). In search of the chains that hold Brazil bank, working paper, Harvard Kennedy School and Center for International Development, August.

Jornal do Comércio (2007). "Rombo de escândalo seria R \$1.5 bi" [Hole from the scandal would be R\$1.5 billion], September 18 .

Kamil, Herman, Sutton, Bennett, and Walker, Chris (2009). A Hedge, Not a Bet, Finance and Development, June, pp. 46-47. 
Krishnamurthy, Arvind (2009). Amplification Mechanisms in Liquidity Crises, NBER Working Paper 15040.

Koyama, Sérgio Mikio. Clodoaldo Aparecido Annibal, Eduardo Lundberg, Fani Lea Cymrot Bader, and Tony Takeda (2008), Decomposição do Spread Bancário e Apresentação de Nova Metodologia [Decomposition of the bank spread presentation of the new methodology], Central Bank of Brazil, Relatório de Economia Bancária e Crédito [Report on banking economy and credit], Chapter 2.

Kumar, Anjali, Ajai Nair, Adam Parsons, and Eduardo Urdapilleta (2006). Expanding Bank Outreach through Retail Partnerships: Correspondent Banking in Brazil, World Bank Research Paper No. 86, June.

Leme, Paulo (2008). Emerging Markets Daily Economic Comment, "Brazil-Bacen Implements Second Round or Measures to Irrigate Banking System." Goldman Sachs, October 6.

Mantega, Guido, and Henrique Meirelles (2008). "Guido Mantega e Henrique Meirelles falam sobre MP-443" [Guido Mantega and Henrique Meirelles discuss Provisional Measure 443], press conference. TV Web Fazenda video, October 22, www.fazenda.gov.br (accessed June 9, 2009).

Meirelles, Henrique (2008). Pronunciamento do Presidente do Banco Central, Henrique Meirelles, na Posse da nova Diretoria da Anbid, Sao Paulo [Statement of Central Bank President Henrique Meirelles at the taking of office of the new board of directors of the National Association of Investment Banks (Anbid)], October 20.

Mesquita, Mário, and Mário Torós (2010a). Brazil and the 2008 panic, Bank for International Settlements conference on The Global Crisis and Financial Intermediation in Emerging Market Economies, January 28-29.

(2010b). Considerações sobre a Atuação do Banco Central na Crise de 2008 [Considerations on the responses of the Central Bank to the crisis of 2008], Central Bank of Brazil Discussion Paper March.

McKinnon, Ronald (1973). Money and Capital in Economic Development, Washington, D.C. Brookings Institution.

Mishkin, Frederic (2004). Can Inflation Targeting Work in Emerging Market Countries? NBER Working Paper 10646, July.

Moffett, Matt (2004). "Economic Discord Begins to Emerge in Brazil's Cabinet," The Wall Street Journal, February 6. 
Montero, Carlos, and Ramon Moreno (2011). The use of reserve requirements as a policy instrument in Latin America, BIS Quarterly Review, March, pp. 53-65.

Morris, Stephen, and Hyun Son Shin (2008). Financial Regulation in a System Context, Brookings Papers on Economic Activity, Fall, pp. 229-61.

Nakagawa, Fernando and Fabio Graner (2010). "BC: compulsório fará parte do future colchão de liquidez," [Central Bank: the compulsory requirements will form part of the future liquidity cushion]. Agência Estado, February 24.

Pereira, Renée (2008). "Estímulo à aquisicao de carteiras falho" [Simulus to the acquisition of loan portfolios failed], O Estado de Sao Paulo, October 23.

Reuters News (2000). "Brazil Cenbank to reinstate director outsted in probe," August 4. (2007). "Brazil's finance min tussles with central banker,” March 21.

Ribeiro, Alex (2009). "BB foi usado como bombeiro da crise Bastidores: Banco assumiu papel de garantidor de liquidez ao sistema, enquanto BC relutava" [Banco do Brasil was used as a fireman during the crisis. Behind the scenes: Bank assumed the role of guarantor of liquidity in the system while the Central Bank resisted]. Valor Econômico, November 24.

Romero, Cristiano (2008). "O arsenal do BC para garantir liquidez" [The arsenal of the Central Bank to guarantee liquidity], Valor Econômico, September 30.

(2010). Autonomia ameaçada [Autonomy threatened], Valor Econômico, December 17.

, and Alex Ribeiro (2009). "Os bastidores da crise" [Behind the scenes of the crisis]. Valor Econômico, November 13.

Salviano Junior, Cleofas (2004). Bancos Estaduais: dos Problemas Crônicos ao Proes [State Government Banks: from the Chronic Problems to Proes], Central Bank of Brazil (available on www.bcb.gov.br).

Shaw, Edward (1973). Financial Deepening in Economic Development, New YorkÇ Oxford University Press.

de Souza Rodrigues, Eduardo Augusto, and Tony Takeda (2004). "Efeitos dos Recolhimentos Compulsórios sobra a Distribuição das Taxas de Juros Bancárias no Brasil" (Effects of Reserve Requirements on the Distribution of Bank Interest Rates in Brazil), in Economia Bancária e Crédito: Avaliaçáo de 5 anos do Projeto Juros e Spread Bancário, Central Bank of Brazil, December. 
Takeda, Tony, and Fani Léa C. Bader (2005). Consignação em Folha de PagamentoFatores da Impulsão do Crédito (Payroll loans-Factors Driving Credit), Central Bank of Brazil, Relatório de Economia Bancária e Crédito.

Tombini, Alexandre, and Sergio Lago Alves (2006). The Recent Brazilian Disinflation Process and Costs, Central Bank of Brazil Working Paper Series 109, June.

UBS (2005). Focus on Brazil: Understanding the Political Crisis, Latin America Perspectives, August 12.

Valor Econômico (2006a). "Bancos utilizam debêntures para driblar recolhimentos obrigatórios" [Banks use debentures to evade reserve requirements], October 23.

(2006b). "Bancos médios descrobrem a bolsa" [Small and mid-sized Banks discover the stock market], December 18.

(2007). "Setor defende mudança na regra de cessão de carteira" [Sector defends change in the rule on loan portfolio sales], May 7.

(2008a). "BC fala em rigor, mas mercado vê lentidão em normas," [Central Bank talks in rigor but the Market sees slowness in regulations], January 29.

(2008b). "Nova regra do BC pode frear o crédito [New rules of the Central Bank could put a break on credit], February 6.

(2008c) "Volatilidade cresce nos juros bancários" [Volatility rises on bank interest rates], May 12.

(2008d) "FGC comprou 4 carteiras de crédito" [FGC bought 4 loan portfolios], October 9.

(2008e). "Lula faz pressão para liberar recursos [Lula pressures for the release of reserves], October 23.

(2008f). "O futuro dos pequenos e médios bancos" [The future of small and médium banks], October 31.

(2008g). "Divergências entre BB e Votorantim" [Disagreements between Banco do Brazil and Votorantim], December 2.

(2009). "FGC estimula expansão do crédito" [FGC stimulates credit expansion], March 6.

Valor Online (2008). "18 carteiras ja foram compradas,; taxa atinge $150 \%$ do CDI" [18 loan portfolios have so far been bought; rates reach 150 percent of the CDI rate], October 17. 
Figure 1. CDS Premium, Brazil

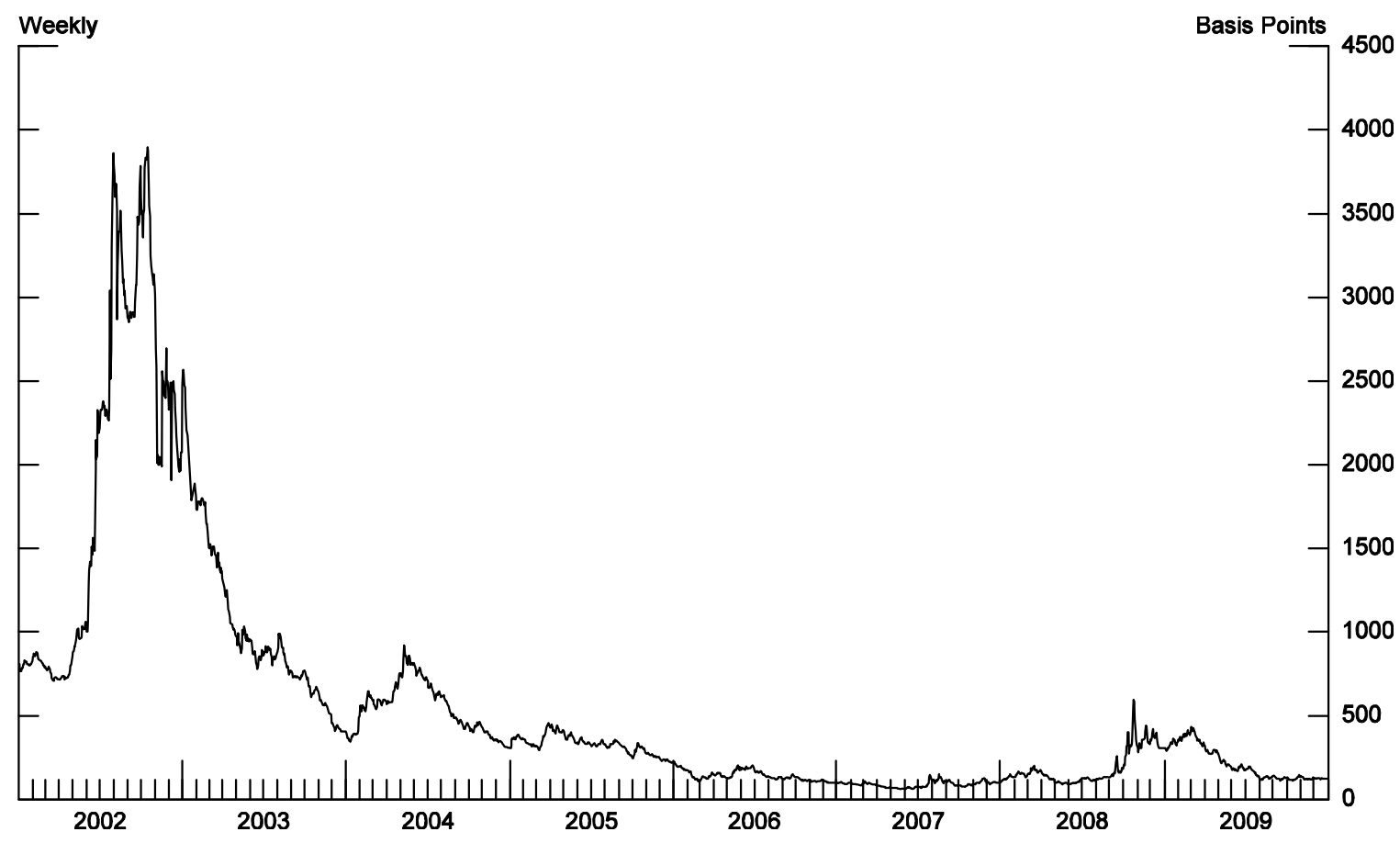

Source: Markit

Figure 2. Selic Rate, Inflation, and Long-Term Inflation Expectations 1999-2009

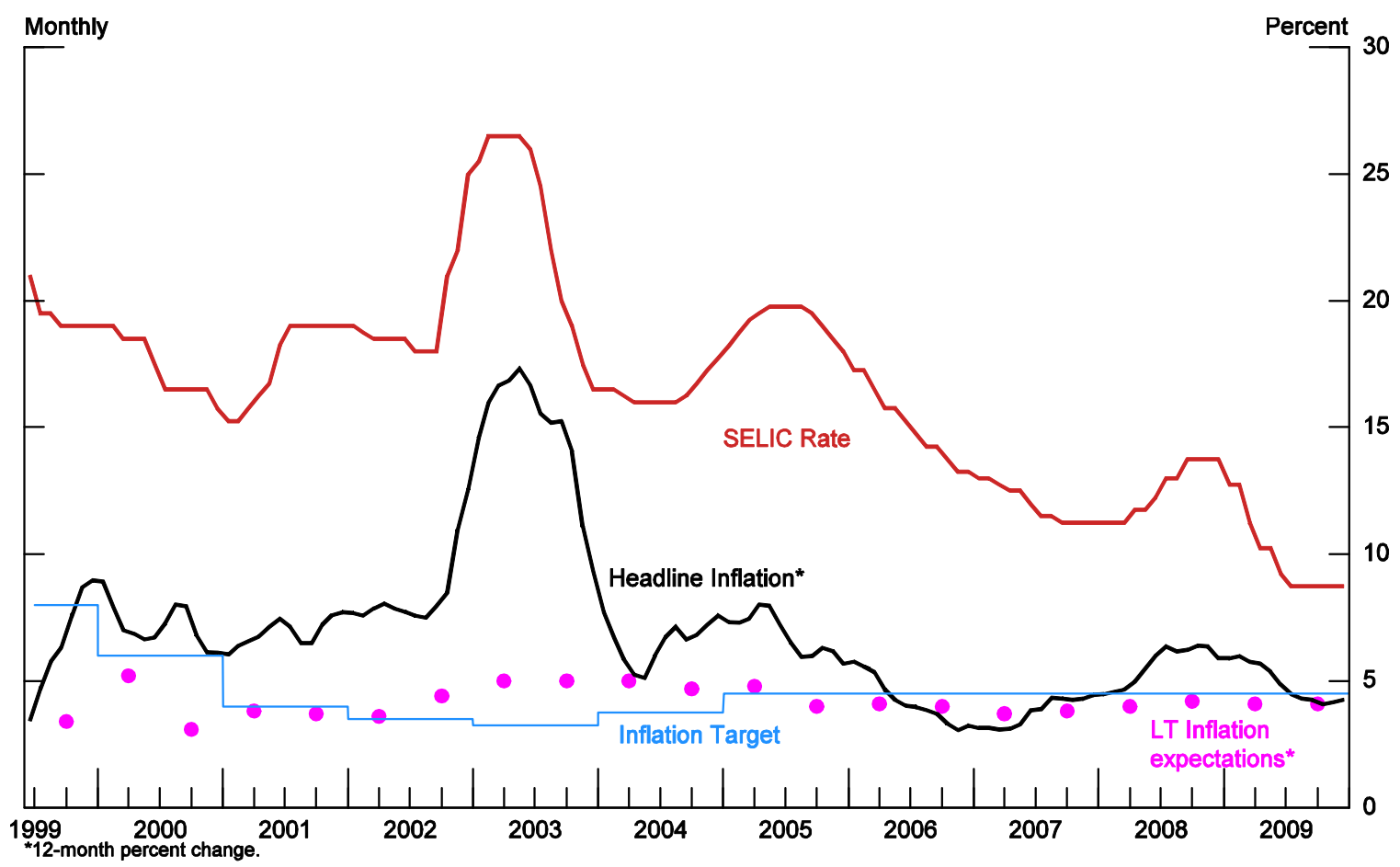

Sources: Central Bank of Brazil, Consensus Forecasts. 


\section{Notes to Figure 2:}

The measure of long-term inflation expectations is the mean forecast of expected longterm inflation (five- to ten-year ahead) from the Consensus Forecasts survey. The survey is conducted every April and October, around the $20^{\text {th }}$ of the month.

The inflation target is for December-December inflation. The tolerance range for the inflation target was not shown and was the following: 1999-2003: $+/-2$ percentage points. 2005 and 2005: $+/-2.5$ percentage points. 2006-2009: 2 percentage points.

Long-term expected inflation is compared with the inflation target. The targets for 1999, 2000, and 2001 were announced in June 1999, when the inflation targeting regime was launched and were clearly intended to be targets under the transition phase. Beginning in June 2000, the inflation targets were announced $1 \frac{1}{2}$ years ahead of time. In mid-2002 the inflation target for 2003 was revised up from 3.25 percent to 4 percent and the tolerance interval of $+/-2$ percentage points was widened to $+/-2.5$ percentage points. In mid-2003, the inflation target for 2004 was revised up from 3.75 percent to 5.5 percent. The tolerance interval was moved back down to $+/-2$ percentage points beginning with the announcement of the 2006 target in mid-2004. The original targets for 2003 and 2004 are compared with long-term inflation expectations because the original target announcement was more likely to be closer to the government's implicit long-term inflation goal. 


\section{Figure 3. Credit to the Private Sector}

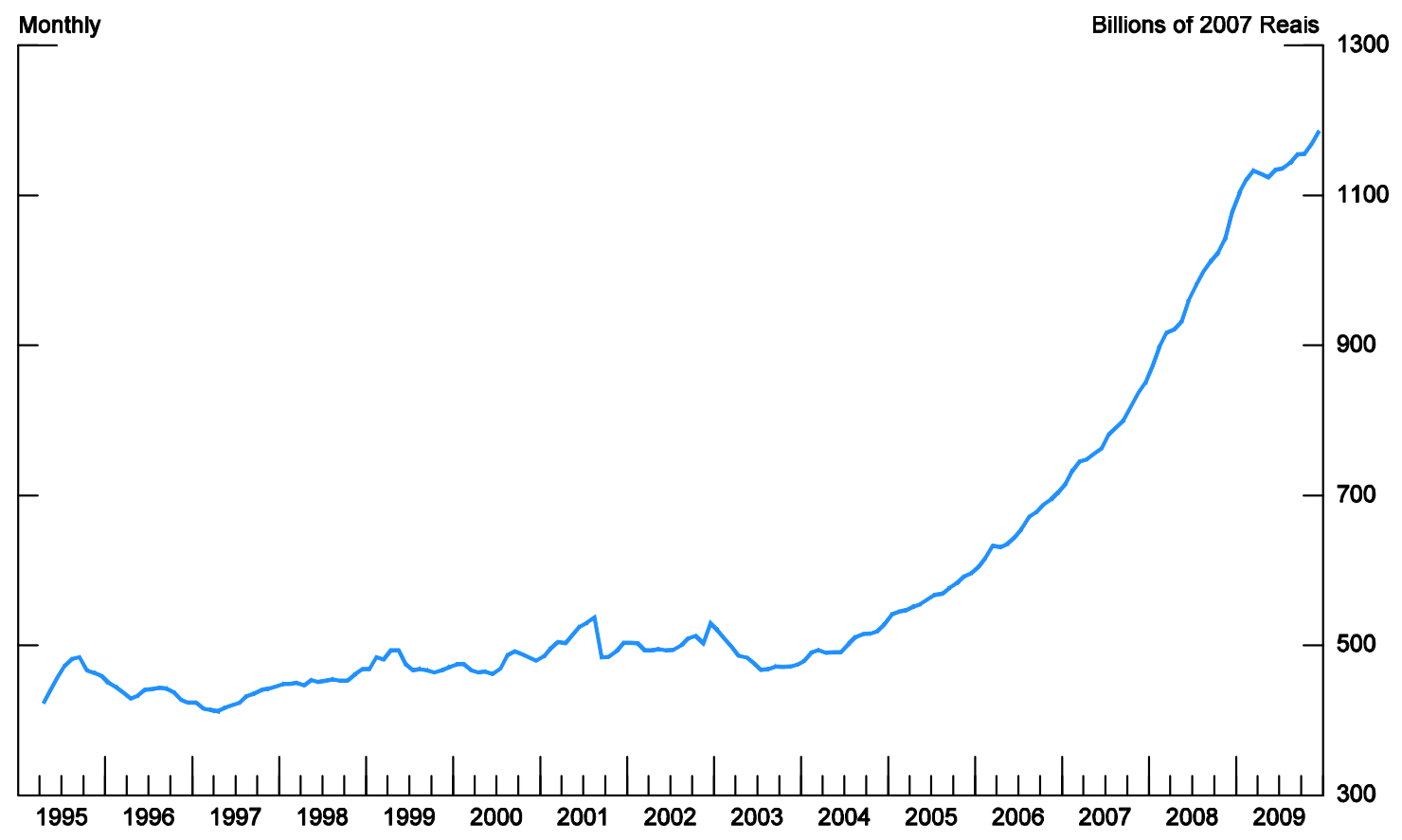

Figure 4. Credit Growth, 2003-2009

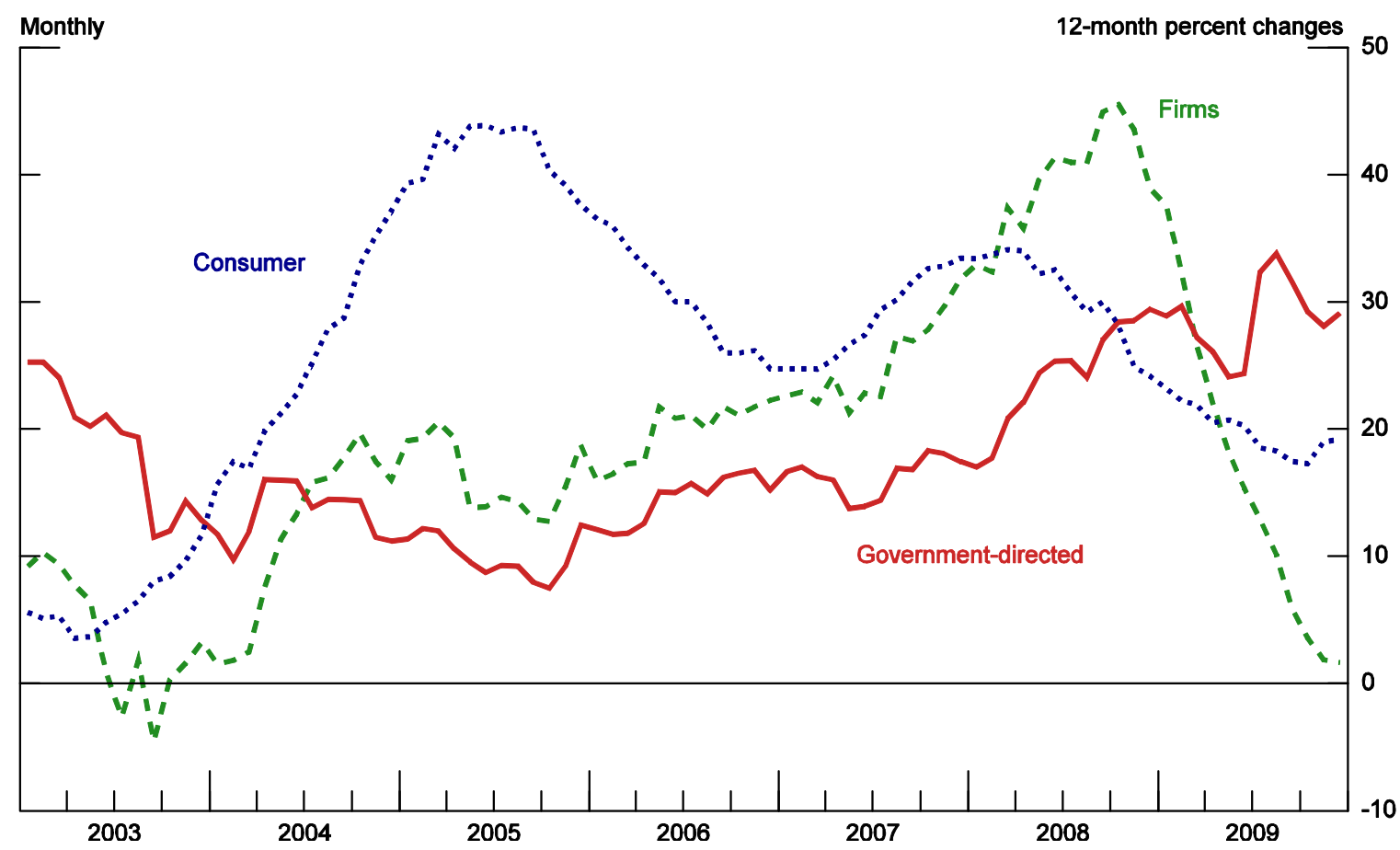

Source of Figures 3 and 4: Central Bank of Brazil. In Figure 3, credit deflated by IPCA. 
Figure 5. Loan-Deposit Spreads and Loan Rates*

\section{a. Spreads}

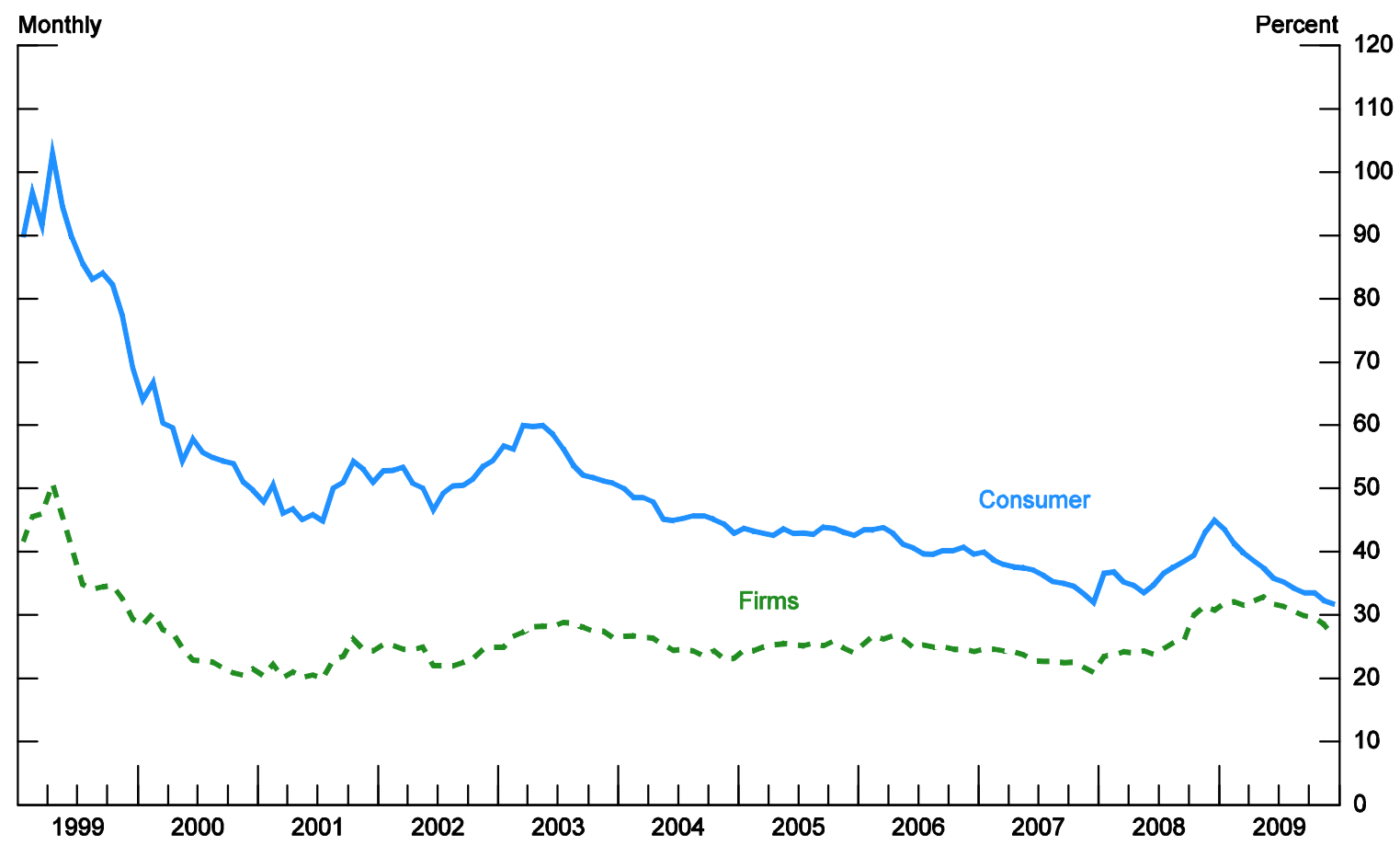

\section{b. Selected Loan Rates}

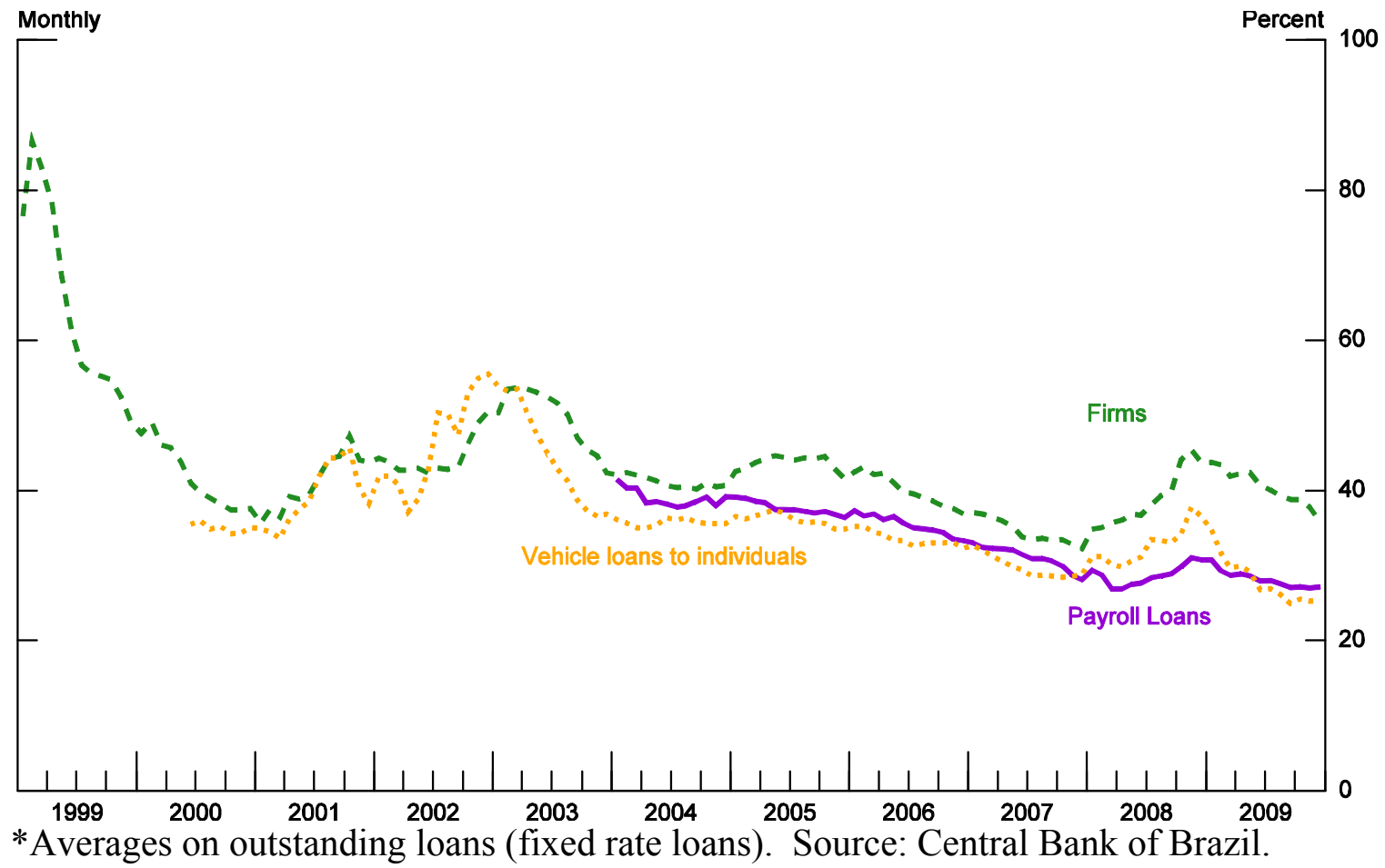


Figure 6. Deposits 1995-2007*

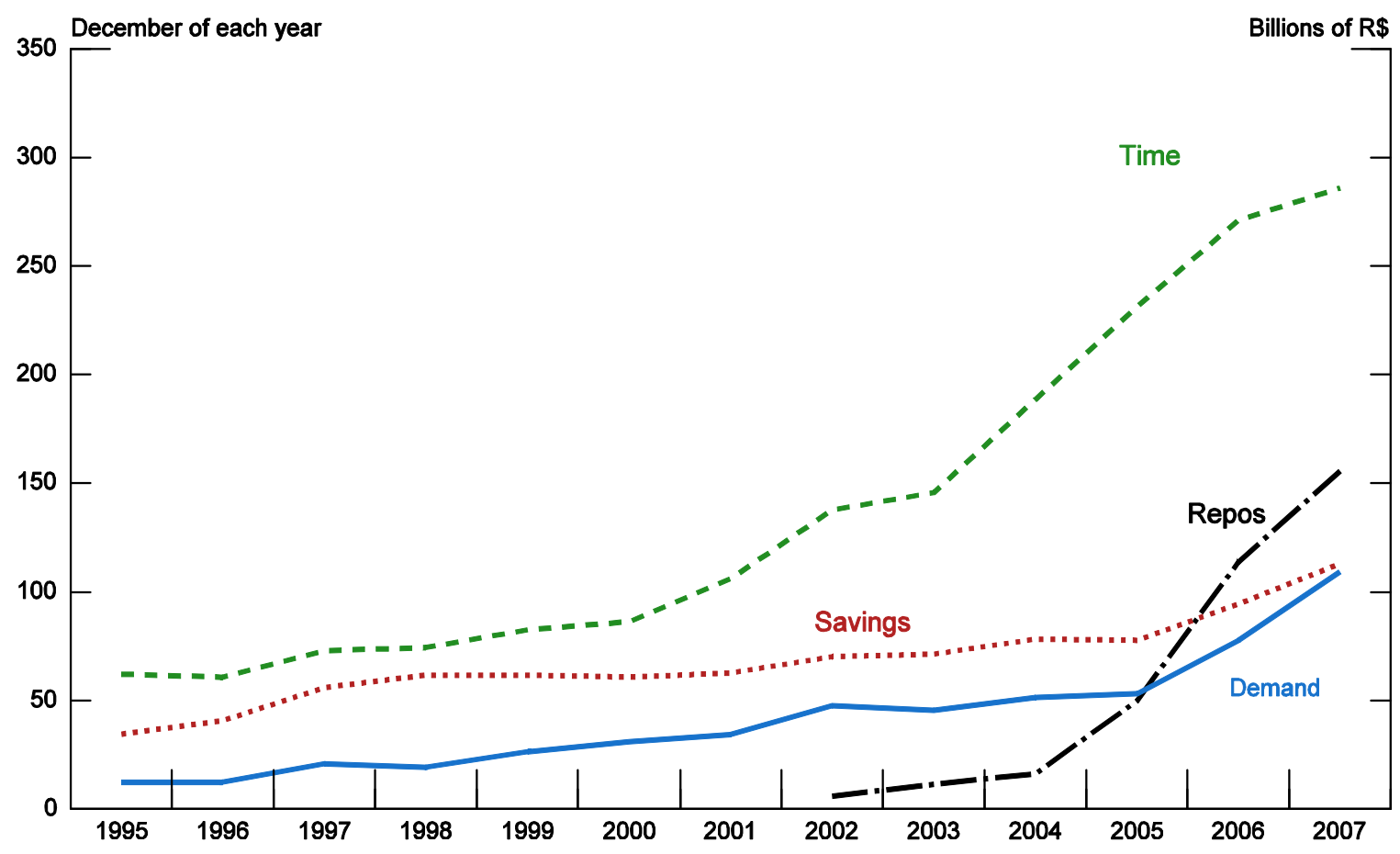

*Excludes federally-owned Banco do Brasil and Caixa Economica Federal. Repos are a time deposit substitute. For details, see text and Appendix A. Sources: Central Bank of Brazil, Comissão de Valores Mobiliários (CVM). 
Figure 7. Quasi-Statutory Reserve Ratios Faced by Large Banks, of which...

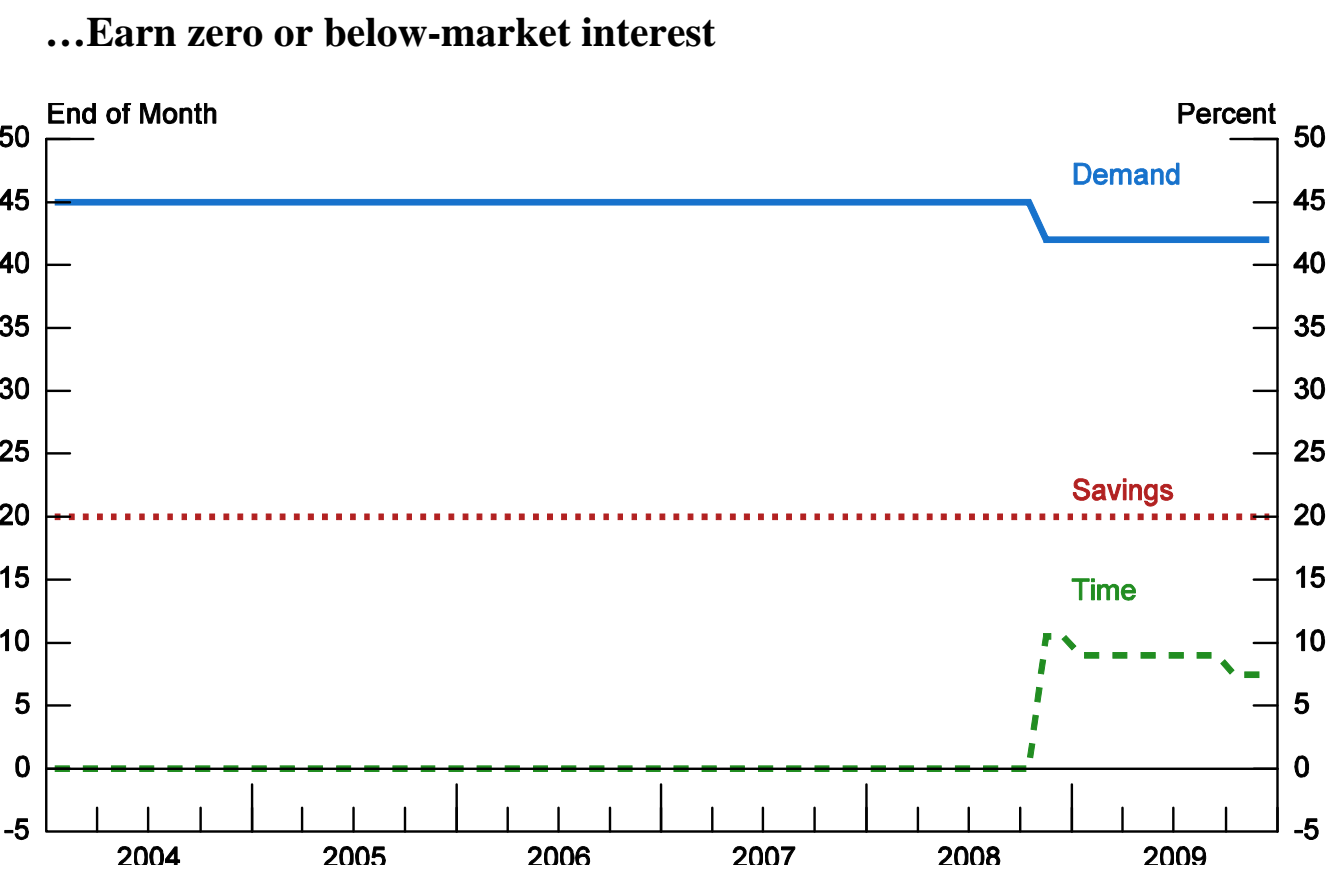

\section{...Earn the Selic Rate}

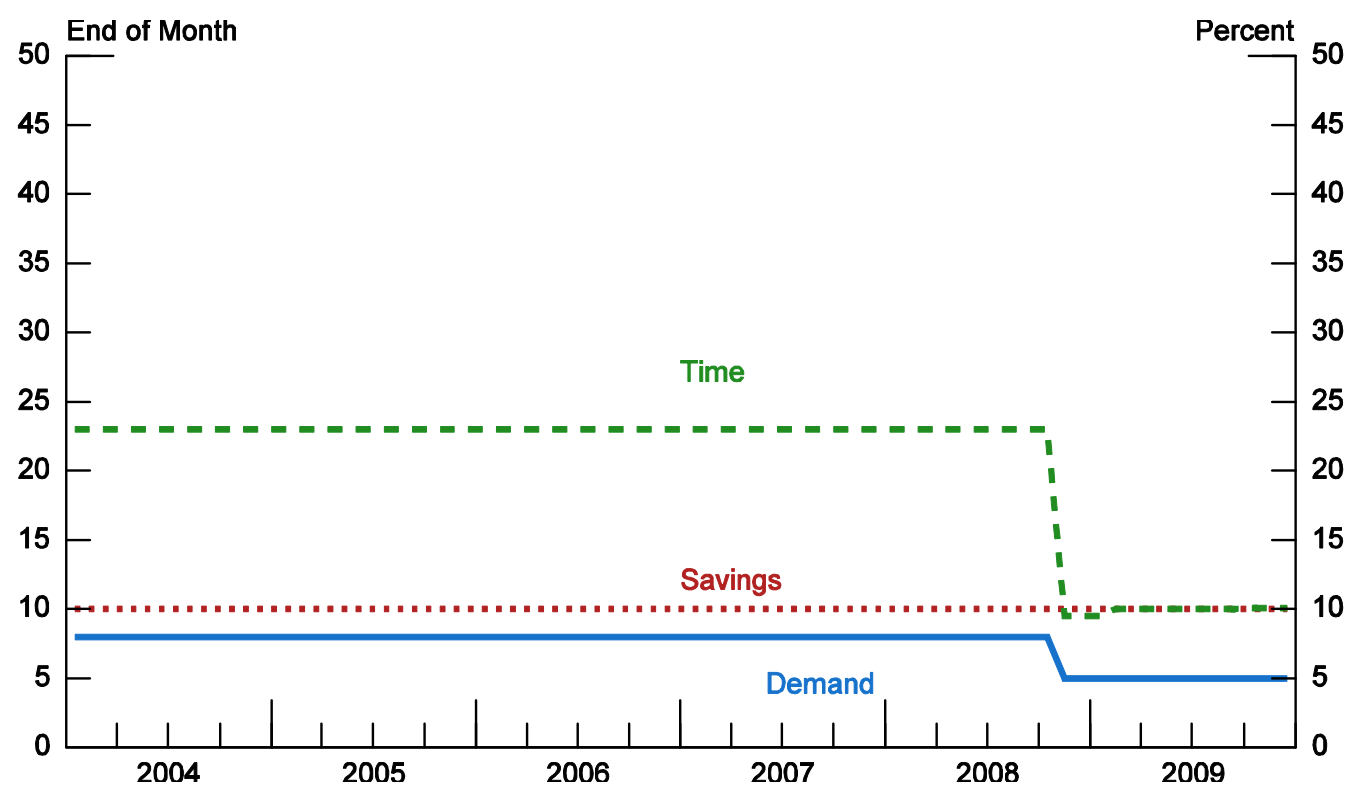

Notes to Figure 7. Author's own calculations. Details are in the text, but further details and data are available from the author upon request. 
Table 1. Major Liabilities of 10 Largest Banks, December 2007 (Figures in billions of reais unless stated otherwise)

\begin{tabular}{|c|c|c|c|c|c|c|c|c|}
\hline & \multirow[t]{2}{*}{ Bank } & \multirow{2}{*}{$\begin{array}{c}\text { Type of } \\
\text { Ownership }\end{array}$} & \multirow[t]{2}{*}{ Liabilities } & \multicolumn{3}{|c|}{ Deposits } & \multirow[t]{2}{*}{$\operatorname{Repos}^{1}$} & \multirow[t]{2}{*}{ \# branches } \\
\hline & & & & Demand & Savings & Time & & \\
\hline 1 & Banco do Brasil & Government & 333.5 & 49.3 & 45.8 & 67.1 & 0 & 4,081 \\
\hline 2 & Itaú & Domestic & 257.9 & 27.5 & 28.0 & 24.1 & 41.1 & 2,593 \\
\hline 3 & Bradesco & Domestic & 253.7 & 28.6 & 32.8 & 38.0 & 29.5 & 3,172 \\
\hline 4 & CEF & Government & 239.1 & 11.5 & 75.6 & 41.4 & 0 & 2,052 \\
\hline 5 & ABN Amro & Foreign & 146.5 & 9.3 & 10.7 & 32.4 & N/A & 1,141 \\
\hline 6 & Unibanco & Domestic & 136.0 & 10.4 & 10.5 & 25.9 & 15.7 & 942 \\
\hline 7 & Santander & Foreign & 107.1 & 6.3 & 6.3 & 25.9 & N/A & 1,084 \\
\hline 8 & HSBC & Foreign & 65.7 & 7.0 & 2.0 & 34.4 & 0 & 933 \\
\hline 9 & Safra & Domestic & 63.1 & 3.7 & 0.8 & 5.8 & 12.3 & 127 \\
\hline \multirow[t]{4}{*}{10} & Votorantim & Domestic & 60.4 & 0.3 & 0 & 13.9 & 15.4 & 13 \\
\hline & Subtotal & & 1,663 & 154 & 213 & 309 & N/A & 16,138 \\
\hline & Total Banking system & & 2,044 & 170 & 234 & 393 & 160 & 18,562 \\
\hline & Number of banks: 101 & & & & & & & \\
\hline
\end{tabular}

Sources: Central Bank of Brazil, banks' financial statements. Outstanding stock of repos in November 2007 is from the Brazilian Central Bank's press release, January 31, 2008.

\footnotetext{
${ }^{1}$ Repos are time deposit substitutes. For details, see text and Appendix A.
} 
Table 2. Statutory Reserve Requirements mid-January 2008

Banks earn zero or below-market interest on reserve balances

\begin{tabular}{lccc}
\hline & demand & saving & time \\
ratio & 45 & 20 & none \\
deductible & R $\$ 44$ million & none & \\
& & \\
\hline
\end{tabular}

Banks earn the Selic rate on reserve balances

Cash requirement

demand saving time

ratio

8

10

8

deductible

$\mathrm{R} \$ 100$ million on sum

Government bond holding requirement

demand saving time

ratio

15

deductible

R\$300 million 


\section{Notes to Table 2:}

1. Required reserves against demand deposits earn no interest.

2. Required reserves against savings deposits (cardenetas de poupança) earn a small spread over the Taxa Referencial or TR (meaning Reference Rate). The TR is administratively set and has been well below market interest rates. For the month of January 2008, the TR was 1.16 percent. The spread over the TR was between 3 and 6.2 basis points (Circular 3093, March 1, 2002). 
Table 3. Reserves held as share of deposits

a. Small and Mid-sized Banks

\begin{tabular}{|c|c|c|c|c|c|c|c|}
\hline & \multirow[t]{2}{*}{$\begin{array}{c}\# \\
\text { banks }\end{array}$} & \multicolumn{3}{|c|}{$\begin{array}{l}\text { 45\% reserve ratio on } \\
\text { demand deposits }\end{array}$} & \multicolumn{3}{|c|}{$\begin{array}{l}15 \% \text { reserve ratio on time } \\
\text { deposits (government bond } \\
\text { holding requirement) }\end{array}$} \\
\hline & & $\begin{array}{c}\text { If no } \\
\text { deductible } \\
(\%)\end{array}$ & $\begin{array}{l}\text { Actual* } \\
\quad(\%)\end{array}$ & $\begin{array}{l}\text { \# banks } \\
\text { with } \\
\text { reserves } \\
>0\end{array}$ & $\begin{array}{c}\text { If no } \\
\text { deductible } \\
(\%)\end{array}$ & $\begin{array}{l}\text { Actual* } \\
\quad(\%)\end{array}$ & $\begin{array}{l}\text { \# banks } \\
\text { with } \\
\text { reserves } \\
>0\end{array}$ \\
\hline Total & 81 & 45 & 29.0 & 13 & 15 & 3.9 & 9 \\
\hline Domestic & 50 & 45 & 15.6 & 9 & 15 & 1.9 & 6 \\
\hline Foreign & 31 & 45 & 37.1 & 4 & 15 & 3.3 & 3 \\
\hline
\end{tabular}

b. Five Large Banks

45\% reserve requirement on demand deposits

15\% government bond holding requirement on time deposits

\begin{tabular}{ccccc}
\hline If no deductible & $\begin{array}{c}\text { Actual* } \\
\mathbf{( \% )}\end{array}$ & $\begin{array}{c}\text { If no } \\
\text { deductible } \\
\mathbf{( \% )}\end{array}$ & $\begin{array}{c}\text { Actual* } \\
\mathbf{( \% )}\end{array}$ & $\begin{array}{c}\text { With } \\
\text { deductible, } \\
\text { including repos } \\
\mathbf{( \% )}\end{array}$ \\
\hline 45 & 44.7 & 15 & 13.6 & 7.0 \\
\hline
\end{tabular}

Notes to Tables $3 \mathrm{a}$ and 3b: * means that the ratios are the author's estimates. Small and mid-sized banks exclude both the top ten banks and government-owned banks. The five large banks in Table $3 \mathrm{~b}$ are Itau, Bradesco, Unibanco, Votorantim, and Safra. 
Table 4. Time Deposits

\begin{tabular}{|c|c|c|c|c|c|}
\hline \multirow[b]{2}{*}{10 Largest banks as of September 2008} & \multicolumn{3}{|c|}{ In $\$ R$ billions } & \multicolumn{2}{|c|}{ \% change } \\
\hline & June & Sept & Dec & Jun-Sept'08 & Sept-Dec'08 \\
\hline 1. Banco do Brasil & 79.9 & 111.5 & 134.3 & 39.5 & 20.5 \\
\hline 2. Itaú & 34.2 & 60.8 & 92.8 & 77.8 & 52.6 \\
\hline 3. Bradesco & 62.3 & 76.6 & 98.4 & 23.1 & 28.4 \\
\hline 4. Santander & 84.8 & 88.1 & 86.8 & 3.9 & -1.5 \\
\hline 5. CEF & 45.5 & 46.3 & 48.6 & 1.7 & 5.0 \\
\hline 6. Unibanco & 36.5 & 41.1 & 38.2 & 12.5 & -7.1 \\
\hline 7. HSBC & 43.9 & 53.0 & 52.4 & 21.8 & -1.2 \\
\hline 8. Votorantim & 18.8 & 22.5 & 14.6 & 19.3 & -34.8 \\
\hline 9. Safra & 5.5 & 8.1 & 9.1 & 47.4 & 10.7 \\
\hline 10. NCNB & 18.8 & 19.7 & 21.7 & 3.9 & 10.3 \\
\hline \multicolumn{6}{|l|}{ Other banks, of which } \\
\hline Foreign & 22.2 & 20.9 & 19.2 & -6.0 & -8.0 \\
\hline Domestic & 40.5 & 40.0 & 31.4 & -1.2 & -21.6 \\
\hline Federal/State & 36.1 & 36.5 & 38.2 & 1.2 & 5.0 \\
\hline
\end{tabular}




\section{Notes to Table 4:}

Time deposits are based on the Central Bank of Brazil's "50 Largest Banks" database except for Itaú and Unibanco. Itaú's time deposits for June and September 2008 were taken from the consolidated financial statements of Banco Itaú Holding Financeira. For December 2008, time deposits were taken from the financial statements of Banco Itaú Unibanco Banco Multiplo. excluding Unibanco (documents DCC300608, DCC300908, and DCC311208, downloaded from Itaú -Unibanco's website). Unibanco's time deposits are from monthly financial statements that are available on the central bank's website. Because Unibanco's financial statements were not reported for December 2008, November 2008 was used instead. For Banco Santander, deposits in June 2008 is the sum of ABN Amro's and Santander's deposits. Santander acquired ABN Amro in mid-2008. 
Table 5. Cash and Government Securities Held under Reserve Requirements and Reverse Repurchase Agreements, September 30, 2008 (in billions of reais)

\begin{tabular}{|c|c|c|}
\hline & All banks & 8 Large banks (\#) \\
\hline A. Assets held in fulfillment of reserve requirements & & \\
\hline Cash reserves (reserve balances at central bank plus vault cash) & 172 & 164 \\
\hline Government securities & 100 & 89 \\
\hline Total & 272 & 253 \\
\hline Memo: Required reserves that pay zero or below-market interest & 108 & 103 \\
\hline B. Government securities held under reverse repurchase agreements & 305 & NA \\
\hline
\end{tabular}

\# The 7 largest banks shown in Table 2 plus Nossa Caixa Nosso Banco (NCNB), the state bank of Sao Paulo. 


\section{Notes to Table 5:}

Sources:

Total required reserves (in both cash and in the form of government bonds) are from Brazilian central bank's press release on money and credit, April 2009, Table 8. Large banks' holdings of cash and government securities to satisfy reserve requirements were estimated, based on the bank balance sheets that are available from the central bank and using banks' financial statements to make further adjustments. The estimates take into account that the judicial time deposits that are held by Banco do Brasil and CEF are not subject to reserve requirements. (Judicial deposits are deposits that are held in escrow pending the outcome of lawsuits.) Government securities held under reverse repurchase agreements is taken from the central bank's September 2008 financial statement. 
Table 6. Statutory and Quasi-Statutory Reserve Requirements in the Fall of 2008

a. Reserve requirements earning zero or well below-market interest

\begin{tabular}{|c|c|c|c|c|c|}
\hline \multirow[t]{2}{*}{ Date Announced } & \multirow[t]{2}{*}{ Date Effective } & \multicolumn{3}{|c|}{ Ratio (\%) } & \multirow[t]{2}{*}{ Comments } \\
\hline & & Demand & Savings & Time & \\
\hline Previous & & 45 & 20 & 0 & $\begin{array}{l}\mathrm{R} \$ 44 \text { million deductible on demand deposits left unaltered over } \\
\text { the crisis period. }\end{array}$ \\
\hline October 14 & October 29 & 42 & & & \\
\hline October 24 & October 24 & & & & $\begin{array}{l}\text { Bank may deduct prepayment on deposit insurance premiums } \\
\text { (maximum of } 60 \text { months of premiums). }\end{array}$ \\
\hline October 30 & November 14 & & & 10.5 & $\begin{array}{l}10.5 \%=0.7 * 15 \% \text {, but bank may elect instead to provide certain } \\
\text { types of funding to small and mid-sized banks. For details, see } \\
\text { text. }\end{array}$ \\
\hline December 19 & January 5, 2009 & & & 9 & $\begin{array}{l}9 \%=0.6 * 15 \% \text {, but bank may elect instead to provide certain types } \\
\text { of funding to eligible banks. For details, see text. }\end{array}$ \\
\hline
\end{tabular}


b. Cash reserve requirement earning Selic rate

\begin{tabular}{llcccc}
\hline Date Announced & Date Effective & \multicolumn{3}{c}{ Ratio (\%) } & Deductible (applied to the sum) \\
& & Demand & Savings & Time & \\
\hline Previous & & 8 & 10 & 8 & $\mathrm{R} \$ 100$ million \\
September 24 & September 29 & & & & $\mathrm{R} \$ 300$ million \\
October 8 & October 10 & & & & $\mathrm{R} \$ 700$ million \\
October 8 & October 13 & 5 & 10 & 5 & $\mathrm{R} \$ 1$ billion \\
October 13 & October 13 & & & & \\
November 13 & December 1 & & 0 & &
\end{tabular}


c. Reserve requirements satisfied by holding government securities that earn Selic rate

\begin{tabular}{|c|c|c|c|c|c|}
\hline \multirow[t]{2}{*}{ Date Announced } & \multirow[t]{2}{*}{ Date Effective } & \multicolumn{3}{|c|}{ Ratio (\%) } & \multirow[t]{2}{*}{ Deductible/notes } \\
\hline & & Demand & Savings & Time & \\
\hline Previous & & & & 15 & $\mathrm{R} \$ 300$ million. \\
\hline October 8 & October 10 & & & & $\mathrm{R} \$ 700$ million \\
\hline October 13 & October 17 & & & & $\mathrm{R} \$ 2$ billion \\
\hline October 30 & November 14 & & & 4.5 & $4.5 \%=0.3 * 15 \% ;$ for details, see text. \\
\hline November 13 & December 1 & 5 & 10 & 9.5 & See notes for details. \\
\hline & & & & & $\begin{array}{l}\text { Extraordinary requirement converted from cash to a government } \\
\text { bond holding requirement. R } \$ 1 \text { billion deductible maintained. } \\
\text { Deductible on other government bond holding requirement, which } \\
\text { is now effectively } 4.5 \text { percent, remains at } \$ 2 \text { billion. }\end{array}$ \\
\hline December 19 & January 16, 2009 & 5 & 10 & 10 & See notes for details. \\
\hline
\end{tabular}




\section{Notes to Tables 6a-c:}

The ratios in red italics are quasi-statutory or de facto statutory reserve ratios because those ratios were not stated explicitly. Date effective refers to beginning of maintenance period.

\section{Table 6a: Reserve requirements that pay zero or well below market interest:}

October 24: Monthly insurance premium is 0.0125 percent of insured deposits.

October 30: 70 percent of the 15 percent reserve requirement on time deposits that had been satisfied by holding government securities must instead be held in form of form of zero interest-bearing balances at the central bank. Banks can deduct from that requirement certain forms of funding to eligible banks. Hence, banks can choose between a zero-interest bearing reserve requirement on time deposits of 10.5 percent of time deposits $(10.5=0.7 * 15)$ or funding to eligible banks.

December 19: Reduced quasi-statutory reserve requirement from 10.5 to 9 percent of time deposits by reducing from 70 to 60 percent the portion of required reserves that must be satisfied with either cash reserves at the central bank (that earn zero interest) or funding to small and mid-sized banks $(9=0.6 * 15$.

\section{Tables $6 b$ and 6c: Reserve requirements that earn the Selic rate:}

There were two types of reserve requirements that earn the Selic rate. The first requirement (introduced in 2002 under Circular 3144 ), was initially a cash requirement. The Circular 3144 requirement is often referred to as the extraordinary requirement (exigibilidade extraordinaria) and was assessed on demand, savings, and time deposits. The second requirement (introduced in 2002 under Circular 3091) was satisfied by holding government bonds that earn the Selic rate and was assessed only on time deposits. Probably the most complicated changes in reserve requirements involved these two requirements. To avoid confusion, the extraordinary reserve requirements will at times be referred to as the Circular 3144 requirements and the government bond holding requirement will be referred to as the Circular 3091 requirement.

To conserve space, Table $6 \mathrm{c}$ leaves out the reserve requirement that was introduced on January 31, 2008 to close a loophole in the reserve requirements on time deposits. For details, see Appendix A. That reserve ratio was scheduled to rise from 15 percent in mid-September 2008 to 20 percent in mid-November 2008 and to 25 percent in mid-January 2009. However, on September 24, 2008, the scheduled increases were postponed by two months. In December 2008, the schedule of further increases was scrapped altogether and the reserve requirement was equalized to that of time deposits.

October 30: No more than 30 percent of required reserves under Circular 3091 can be held in government securities paying Selic rate. The rest must be held in zero interest bearing accounts at the central bank or be used to provide funding to small and mid-sized banks. See text and notes to Table 6a. As a result, the quasi-statutory reserve requirement is 4.5 percent $(4.5=0.3 * 15)$. 